\title{
Demonstration/Validation of the Snap Sampler
}

Cost and Performance: Final Report

Louise Parker, Nathan Mulherin, Gordon Gooch, Tommie Hall, June 2011

Constance Scott, Jay Clausen, William Major, Richard Willey, Thomas Imbrigiotta, Jacob Gibs, and Donald Gronstal

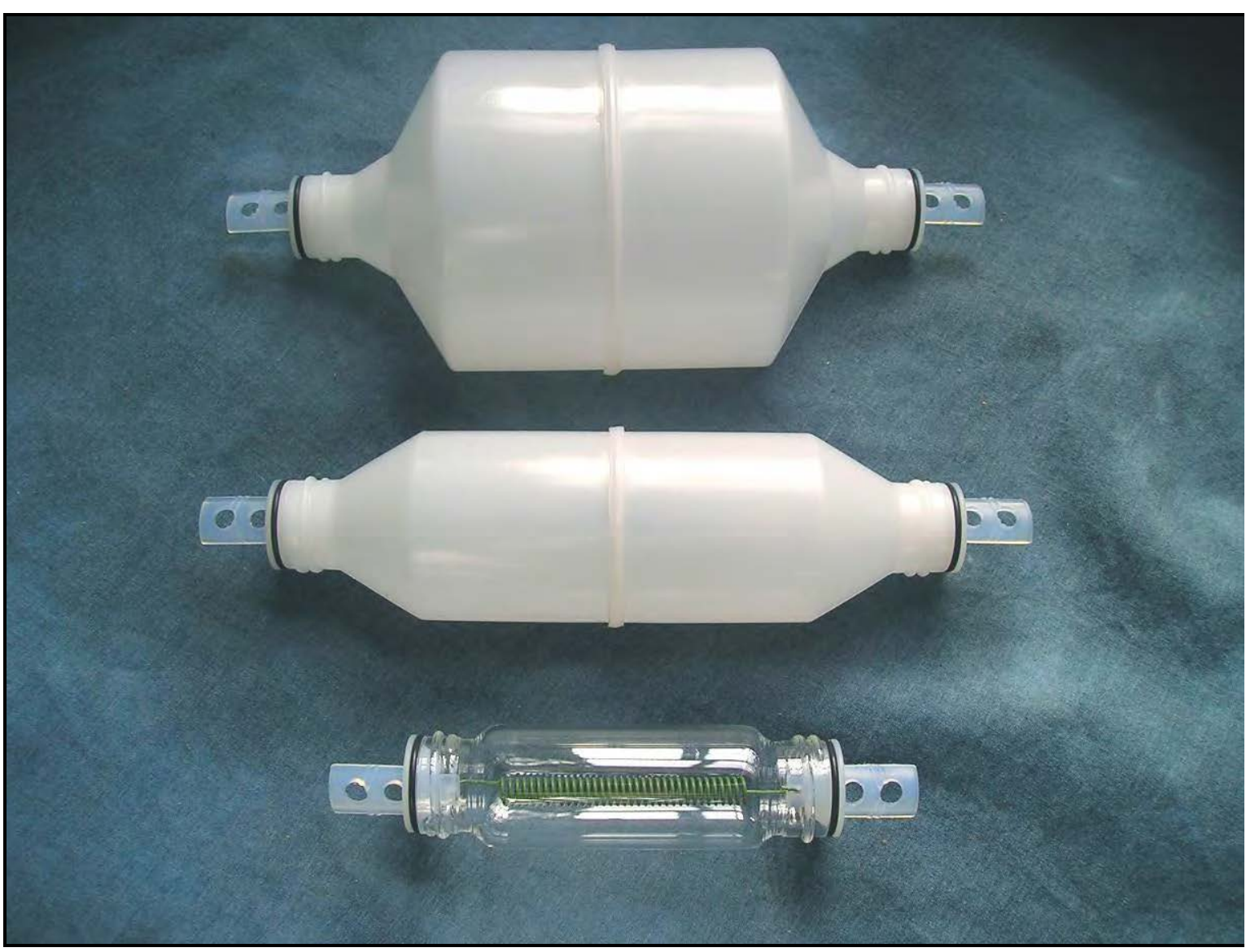




\section{Table of Contents}

1.0 INTRODUCTION......................................................................................1

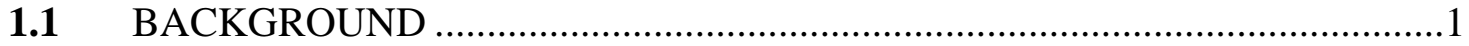

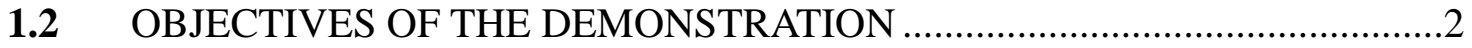

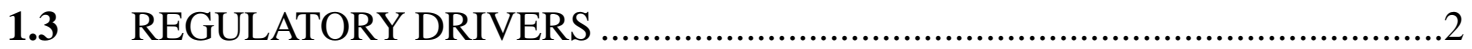

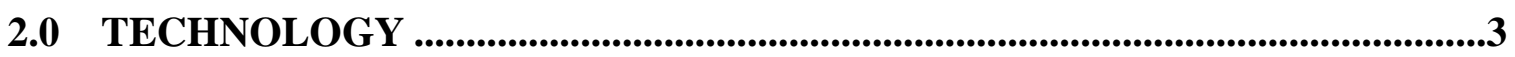

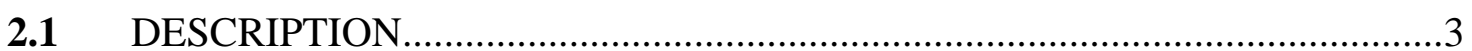

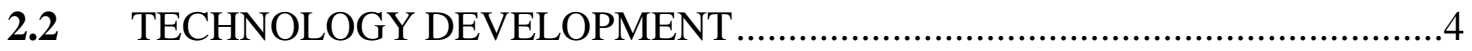

2.3 ADVANTAGES AND LIMITATIONS OF THE TECHNOLOGY ………..........

3.0 DEMONSTRATION DESIGN ……....................................................................

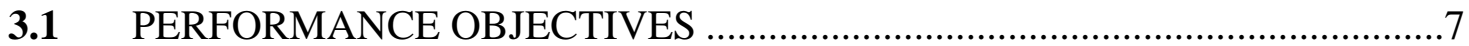

3.2 PROOF-OF-CONCEPT STUDIES FOR INORGANIC ANALYTES..................

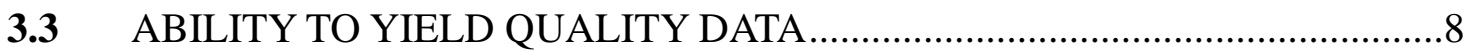

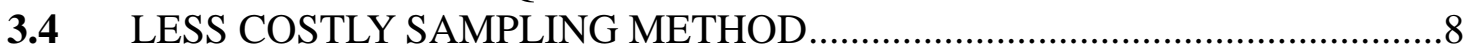

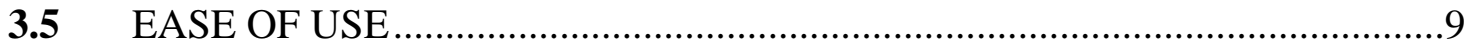

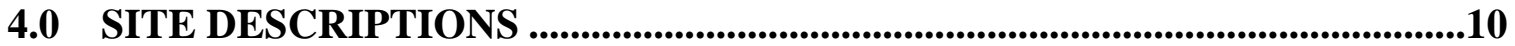

4.1 FORMER PEASE AFB …………………….......................................10

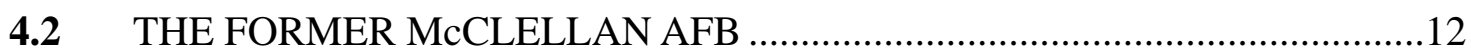

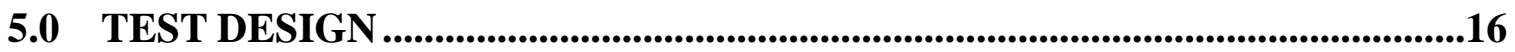

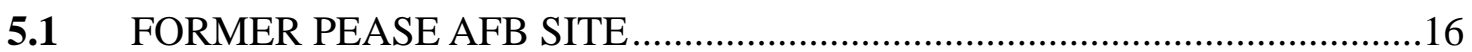

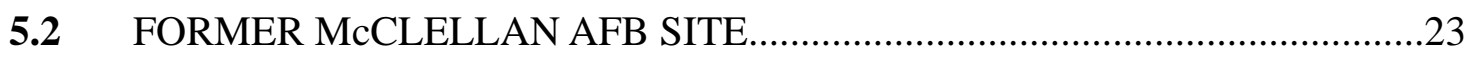

6.0 PERFORMANCE ASSESSMENT.....................................................................31

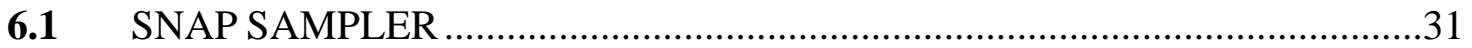

6.2 PERFOMRMANCE ASSESSMENT OF THE RGC SAMPLER.......................35

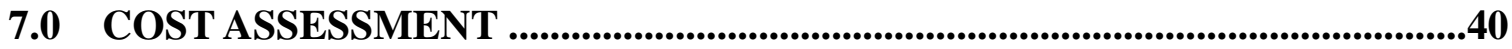

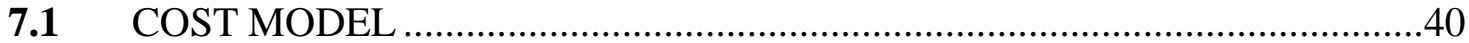

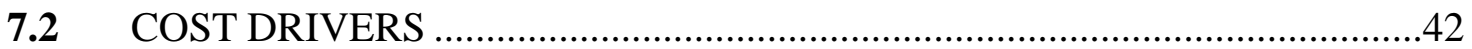

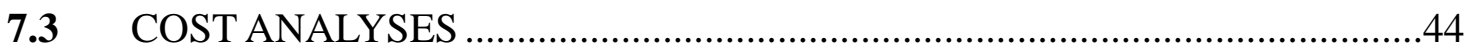

8.0 IMPLEMENTATION ISSUES ……................................................................50

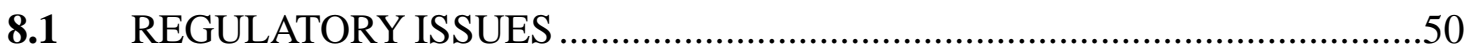

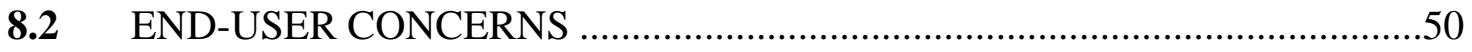

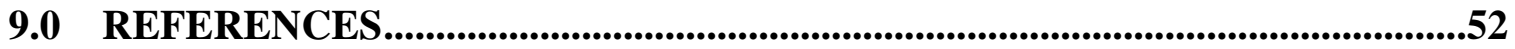

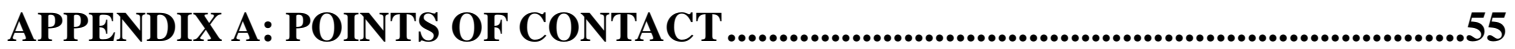


List of Tables

Table 3-1. Performance Objectives for the Snap Sampler and RGC sampler........................7

Table 6-1. Performance of the Snap Sampler at Pease AFB.................................................31

Table 6-2. Performance of the Snap Sampler at the McClellan site. ..................................34

Table 6-3. Performance of the RGC Sampler at Pease AFB..................................................36

Table 6-4. Performance of the RGC sampler at the McClellan Site.....................................38

Table 7-1. Cost model for low-flow sampling. ................................................................40

Table 7-2. Cost model for sampling using Snap Samplers based upon McClellan

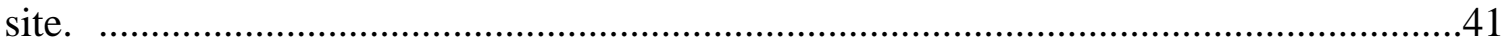

Table 7-3. Cost model for sampling with RGC Samplers. ................................................42

Table 7-4. Projected 10-year monitoring cost using low flow sampling at the Pease site.

Table 7-5. Projected 10-year monitoring cost using the Snap Sampler at the Pease site.

Table 7-6. Projected 10-year monitoring cost using the RGC Sampler at the Pease site.

Table 7-7. Projected 10-year monitoring cost using low-flow sampling at the McClellan site.

Table 7-8. Projected 10-year monitoring cost using the Snap Sampler at the McClellan site.

Table 7-9. Projected 10-year monitoring cost using the RGC sampler at the McClellan site. 
List of Figures

Figure 2-1. Snap Sampler deployment procedure showing a 40-mL VOA vial and 125-mL HDPE bottle.

Figure 4-1. Location of the former Pease AFB............................................................10

Figure 4-2. Former McClellan AFB (adapted from Google 2009).................................13

Figure 4-3. Extent of volatile organic compound contamination in groundwater at McClellan Air Force Base (adapted from Parsons 2004). ............................................15

Figure 5-1. Deployment of sampling equipment in each well......................................19

Figure 5-2. Linear plot of the Snap Sampler and low-flow data for total Mg.................21

Figure 5-3. Linear plot of the Snap Sampler and low-flow data for total Fe....................21

Figure 5-4. Plot comparing concentrations of total and dissolved Mg in the Snap

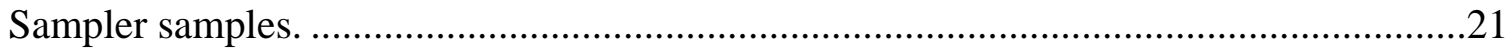

Figure 5-5. Figure showing the deployment of the sampling equipment in the wells at the McClellan site.

Figure 5-6. Snap Sampler samples showing black particles and piece of rusted casing (inside VOA vial). .28

Figure 5-7. Top of RGC sampler showing deposits of large black and orange particles. .28

Figure 5-7. Snap Samplers containing an orange precipitate. 


\section{List of Acronyms, Abbreviations, and Symbols Used in the Text}

\begin{tabular}{ll} 
Analytes and Compounds \\
As & Arsenic \\
$\mathrm{Ba}$ & Barium \\
$\mathrm{BTEX}$ & Benzene, Toluene, Ethylbenzene, Xylene \\
$\mathrm{Ca}$ & Calcium \\
$\mathrm{Cd}$ & Cadmium \\
$\mathrm{cDCE}$ & cis,1,2-DCE \\
$\mathrm{Cl}$ & Chloride \\
$\mathrm{Co}$ & Cobalt \\
$\mathrm{Cr}$ & Chromium \\
$\mathrm{Cu}$ & Copper \\
$\mathrm{DCE}$ & Dichloroethylene \\
$\mathrm{Fe}$ & Iron \\
$\mathrm{K}$ & Potassium \\
$\mathrm{Mg}$ & Magnesium \\
$\mathrm{Mn}$ & Manganese \\
$\mathrm{Mo}$ & Molybdenum \\
$\mathrm{MTBE}$ & Methyl Tert-Butyl Ether \\
$\mathrm{Na}$ & Sodium \\
$\mathrm{Ni}$ & Nickel \\
$\mathrm{Pb}$ & Lead \\
$\mathrm{PCE}$ & Tetrachloroethylene \\
$\mathrm{TCE}$ & Trichloroethylene \\
$\mathrm{V}$ & Vanadium \\
$\mathrm{Zn}$ & Zinc \\
& \\
\hline
\end{tabular}

Other

AFB

ANOVA

Air Force Base

ASTM

Analysis of Variance

American Society for Testing and Materials (now known as ASTM

International)

bgs

Below Ground Surface

COC

Contaminants of concern

CRREL

Cold Regions Research and Engineering Laboratory

DI

deionized, distilled water

DoD

US Department of Defense

EPA

US Environmental Protection Agency

ERDC

GC/MS

US Army Engineer Research and Development Center

gpd

Gas Chromatography/Mass Spectrometry

Gallons per Day

HDPE

High Density Polyethylene

ICP/MS

ITRC

$\$ K$

Inductively Coupled Plasma Mass Spectrometry

Interstate Technology and Regulatory Council

thousand dollars

LAAP

Louisiana Army Ammunition Plant 


$\begin{array}{ll}\text { LDPE } & \text { Low-Density Polyethylene } \\ \text { LTM } & \text { Long Term Monitoring } \\ \text { MCL } & \text { Maximum Contaminant Level } \\ \text { mL } & \text { milliliter } \\ \text { MS } & \text { Matrix Spike sample } \\ \text { MSD } & \text { Matrix Spike Duplicate sample } \\ \text { NJDEP } & \text { New Jersey Department of Environmental Protection } \\ \text { PAH } & \text { Polycyclic Aromatic Hydrocarbon } \\ \text { PDB } & \text { Polyethylene Diffusion Bag sampler } \\ \text { PE } & \text { Polyethylene } \\ \text { POC } & \text { Points of Contact } \\ \text { PP } & \text { Polypropylene } \\ \text { ppb } & \text { parts per billion } \\ \text { PVC } & \text { Polyvinyl Chloride } \\ \text { QA } & \text { Quality Assurance } \\ \text { QC } & \text { Quality Control } \\ \text { RGC } & \text { Regenerated Cellulose } \\ \text { RM-ANOVA } & \text { Repeated Measures Analysis of Variance test } \\ \text { RPD } & \text { Relative Percent Difference } \\ \text { \% RSD } & \text { \% Relative Standard Deviation } \\ \text { VOA } & \text { Volatile Organic Analyte } \\ \text { VOC } & \text { Volatile Organic Compound } \\ \end{array}$




\section{ACKNOWLEDGEMENTS}

The ESTCP program provided the funding for this demonstration. Special thanks go to Dr. Andrea Leeson, Dr. Jeffrey Marquesee, Dr. Anne Andrews, and the ESTCP panel members and technical advisors for the advice and insight they have provided throughout the course of this project.

For assistance at the Pease AFB site, we thank Michael Daly with Region 1 of the U.S. EPA for providing the historical field data, and Martin Mistretta and Jim Bryant of URS Corporation at Pease International Tradeport ${ }^{1}$ for access, scheduling, and general assistance at the field site. Special thanks go to Scott Kelley and Jennifer Lane (Eastern Analytical, Inc.) for conducting the chemical analyses and Sandy Britt (ProHydro, Inc.) for his assistance throughout all the stages of this demonstration and especially for help with developing the wells and for conducting and interpreting the vertical flow testing.

For assistance at the former McClellan AFB, we thank Ken Smarkel, of the Air Force Real Property Agency (AFRPA), for his assistance with setting up the project and handling the initial logistics. Special thanks go to Dale Anderson of URS Corporation (at the McClellan site) for his assistance with access, scheduling, and other issues at the field site, the analysts at Curtis and Tompkins LTD, (Berkeley, CA) for conducting the chemical analyses, and especially Sandy Britt (ProHydro, Inc.) for his assistance throughout all the stages of this demonstration and the flow-meter tests.

We also thank Susan Bigl of USA ERDC-CRREL for her assistance in the final preparation of this report.

This publication reflects the personal views of the authors and does not suggest or reflect the policy, practices, programs, or doctrine of the U.S. Army or Government of the United States. The contents of this report are not to be used for advertising or promotional purposes. Citation of brand names does not constitute an official endorsement or approval of the use of such commercial products.

1 Pease International Tradeport is located on the site of the former Pease Air Force Base. 


\section{EXECUTIVE SUMMARY}

This report was completed as a partial fulfillment of the obligations established for ESTCP Demonstration project ER-0630. The objectives of this demonstration/validation project were to demonstrate that the Snap Sampler passive ground water sampling device can provide 1) technically defensible analytical data for a spectrum of analytes that are of concern to the Department of Defense (DoD) and 2) substantial cost savings.

This research was conducted at two sites: the former Pease Air Force Base (AFB) in Portsmouth, NH, and the former McClellan AFB in Sacramento, CA. There were 10 sampling events at each site and each monitoring well was sampled using Snap Samplers, Regenerated Cellulose (RGC) passive diffusion samplers, and the USEPA Region 1's (1996) low-flow purging and sampling protocol. Analytes that were measured at the Pease site included total and dissolved concentrations of As, Ca, Fe, Mg, Mn, K, and Na. At the McClellan site, samples were collected for a much broader range of analyte types. These included dissolved and total inorganics (including non-metal anions, metalloids, and metals) and four VOCs (three chlorinated solvents and methyl tert-butyl ether [MTBE]).

The performance criteria that were used to determine whether these passive sampling methods provided technically defensible data varied some from site to site. Generally, they included the following: 1) that the method could be used to collect samples for a range of contaminants at the site, 2) that the method provided reproducible results, and 3) that there was agreement between the passive sampling methods and low-flow purging and sampling for the analytes of interest.

The Snap Sampler was able to collect adequate sample volume of for all of the analyses, including requirements for additional QA/QC samples. This was especially significant at the McClellan site, where samples were collected for several different analyte types, which required a relatively large volume of sample.

This sampling method provided reproducible data for the VOCs, dissolved inorganics, and total non-metal ions at both sites. However, at the McClellan site, this was not the case for several of the total metals, where both the Snap Sampler and low-flow samples had high variability between the field duplicate samples for $\mathrm{Cr}$, Fe, and Mn. This was also true for both sampling methods for $\mathrm{Co}, \mathrm{Cu}$, and Mo, although concentrations of these analytes were near the reporting limit. The variability was also greater than our guideline for V with the Snap Sampler samples.

Generally, there was excellent agreement between analyte concentrations in the Snap Sampler and low-flow sampling and these relationships were linear with the slopes equal to 1.0. There were no statistically significant differences between analyte concentrations in the Snap Sampler and the low-flow sampling for the VOCs, dissolved inorganics, total non-metal anions, and most of the total metals and metalloids. The exceptions to this were for total Fe (at both sites) and total Mn (at the McClellan site) where concentrations were significantly higher in the Snap Sampler samples. 
We believe that there may have been several causes for the elevated concentrations of total Fe and Mn in the wells and in the Snap Sampler samples and the poor reproducibility of the two sampling methods for the total metals, and that the causes varied from well to well. These include: 1) leaching of metal constituents of the stainless steel screens and low-carbon steel casing and screen; 2) corrosion of the well screens allowing fines to enter the well; and 3) agitation of the well caused when all the sampling equipment (i.e., bladder pump, baffles, Snap Samplers, and RGC samplers) were placed in the well. This agitation elevated the turbidity in the well and caused the formation of hydrous iron and possibly manganese oxides.

The Snap Sampler was found to be relatively easy to use, especially with the improvements in design and construction as the demonstration progressed.

The Snap Sampler also provided lower sampling costs than low-flow sampling. The longterm costs associated with using the three sampling methods were calculated based on the costs for this demonstration. Long-term monitoring costs were extrapolated for each site assuming that there were 50 wells and quarterly sampling was conducted over 10 years. The cost savings associated with using the Snap Sampler was $46 \%$ at the McClellan site and $67 \%$ at the Pease site. The primary difference in the cost savings was attributed to the larger number of sample bottles that were needed at the McClellan site, where samples were collected for broader spectrum of analyte types. Much of the cost savings were a result of the reduced sampling time needed to collect samples.

Because of the small pore size of the membrane in the RGC samplers, these samplers could not be used to collect samples for total inorganic analytes. For those analytes for which this sampler could be used, there was generally good agreement between the field replicate samples.

The RGC sampler recovered equivalent concentrations of some but not all VOCs. MTBE and acetone were detected in the RGC samples but not in the low-flow or Snap Sampler samples, and TCE concentrations were significantly lower in the RGC samplers than in the low-flow samples. For the dissolved metals and metalloids, there was good agreement between low-flow sampling and the RGC sampler for As, $\mathrm{Ca}, \mathrm{Cr}, \mathrm{Ni}$, and V. Concentrations were significantly higher for $\mathrm{Ba}, \mathrm{Mg}, \mathrm{K}$, and $\mathrm{Na}$ in the RGC sampler although, these differences were very small in magnitude.

Because the RGC sampler can undergo biodegradation, using this sampler can necessitate two trips to the field: one to deploy the sampler and the other to retrieve the samples. However, the time needed for sampling with this sampler is less than one-third of that needed for low-flow sampling. The cost savings for this sampler was $67 \%$ at the McClellan site and $71 \%$ at the Pease site. 


\subsection{INTRODUCTION}

\subsection{BACKGROUND}

Low-flow purging and sampling methods (Puls and Barcelona 1996; USEPA Region 1 1996; ASTM 2003) are commonly used but are expensive because of 1) the time involved in waiting for purge parameters to stabilize, 2) the capital cost of the dedicated equipment (pumps vs. costly and questionably effective decontamination of the equipment between sampling events), and 3) in many instances, the costs associated with disposing of the purge water. Also, low-flow sampling causes extensive mixing within the well and well bore, and this prevents vertical profiling of the contaminant plume, which may be desired. Given the staggering costs associated with long-term monitoring for Department of Defense (DoD) and the nation, finding a sampling method that is less labor-intensive and less costly but able to yield quality data is clearly needed.

Because of their ease of use and cost-savings, passive (or no-purge) groundwater sampling techniques continue to garner interest from the user and regulatory communities. Passive sampling techniques rely on the continuous natural flow through the well screen (Robin and Gillham 1987; Powell and Puls 1993). Most research to date (Michalski 1989; Gillham et al. 1985; Robin and Gillham 1987; Powell and Puls 1993) indicates that water in the screened portion of the well is representative of the formation if the well has been designed and developed properly. Therefore, where the use of passive sampling is appropriate, it can provide better delineation of contamination with depth within the screened zone (in stratified wells), and cost savings owing to reduced volumes of purge water waste, reduced labor during sampling, and reduced equipment costs.

Although the improvements and potential cost savings associated with passive sampling are significant, most passive sampling devices have limitations. For example, the Passive Diffusion Bag (PDB) sampler can only be used for VOCs, and all diffusion samplers yield a concentration that is a time-weighted average over the last several days of the equilibration period (as compared with samples that are collected in "real time").

This study focuses on the performance of another passive sampler-the Snap Sampler. This sampler can be used to obtain whole water samples in real time. This device is deployed in the well and left for an equilibration period. This equilibration period allows time for the well to recover from any disturbance caused by placing the device in the well, allows time for the natural flow pattern in the well to be reestablished, and for the materials in the sampler to equilibrate with the analytes in the well water, thereby preventing losses of analytes due to sorption by the sampler materials. Also, by allowing time for the well to recover prior to collecting the sample, the well is less agitated during the sampling event and particles that are not normally mobile in the formation are less likely to be entrained in the sample when it is collected. Once the equilibration period is complete, the Sampler is triggered and the sample is sealed under in-situ conditions. Thus, this technology allows one to sample a discrete depth within the well. 


\subsection{OBJECTIVES OF THE DEMONSTRATION}

The objectives of this demonstration/validation project were to demonstrate that the Snap Sampler passive ground water sampling device can provide: 1) technically defensible analytical data for the wide spectrum of analytes that are of concern to the DoD and 2) substantial cost savings.

For this demonstration, analyte concentrations in samples collected with the Snap Sampler and Regenerated Cellulose Diffusion sampler were compared with concentrations in samples collected using low-flow purging and sampling (USEPA Region 1, 1996). This demonstration was conducted at two sites: the former Pease Air Force Base (AFB) (Portsmouth, NH) and the former McClellan AFB in (Sacramento, CA). Using these three sampling technologies allowed us to compare dissolved and colloid-borne contaminants (such as metals and the more hydrophobic organic contaminants).

Analytes at the Pease AFB included a range of inorganic analytes including non-metals, transition metals, alkaline earth metals, alkali metals, and a metalloid. Analytes found the McClellan site included four VOCs and a suite of inorganic analytes, including two non-metal anions, a metalloid, two alkali metals, three alkaline earth metals, and nine transition metals. At both sites, dissolved and total inorganic analyte concentrations were determined.

\subsection{REGULATORY DRIVERS}

Currently, the preferred method for sampling a groundwater monitoring well is to use a low-flow purging and sampling method first outlined by Puls and Barcelona (1996) and now promulgated by the USEPA Region 1 (1996), Nielsen and Nielsen (2002), and the ASTM (2003). However, as mentioned previously, this sampling method is time consuming and expensive, and draws wa-

ter most heavily from the most permeable part of the formation, which may or may not be the zone of interest. 


\subsection{TECHNOLOGY}

\subsection{TECHNOLOGY DESCRIPTION}

The Snap Sampler is a grab-type sampling device that was initially developed by Sanford Britt of ProHydro, Inc., to improve data quality for VOCs. However, the applicability of this device to a broad spectrum of analytes was evident immediately because this sampler collects a whole-water sample under in-situ conditions.

The Snap Sampler consists of the sampler body that holds the sample bottle in place, a sample bottle that is open on both ends, a trigger mechanism with the trigger line, and a docking station (Fig. 2-1). The device is deployed so that both ends of the sample bottle are open, and the trigger releases spring-activated end caps that seal the bottle. The trigger line is attached to a well docking station during deployment; this ensures that the sampler remains at the desired depth in the well.
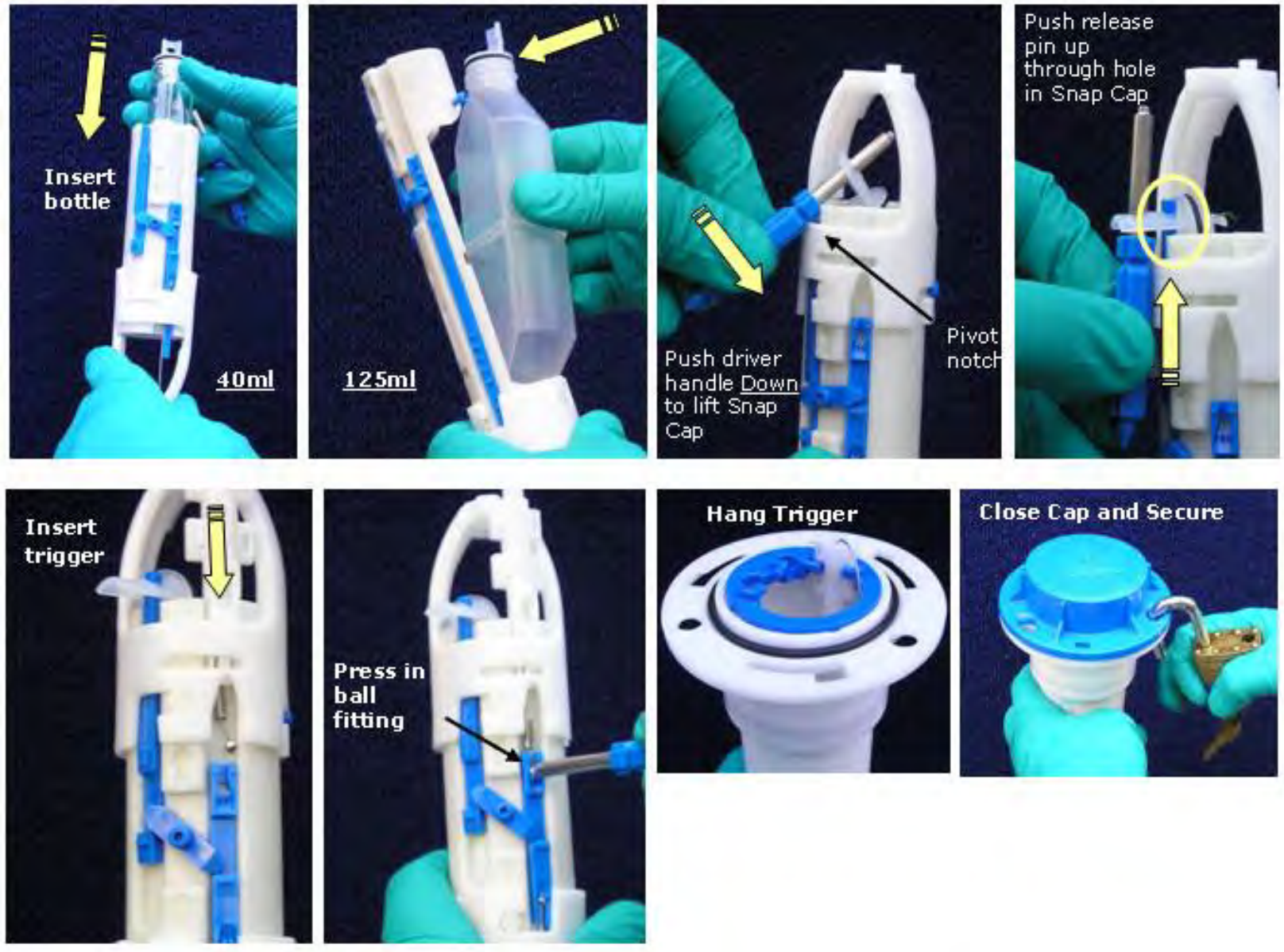

Figure 2-1. Snap Sampler deployment procedure showing a $40-\mathrm{mL}$ VOA vial and 125-mL HDPE bottle. 
Sizes of Snap Sampler bottles include: $40-\mathrm{mL}$ glass volatile organic analyte (VOA) vials, and 125-mL and 350-mL high-density polyethylene (HDPE) bottles. The larger (350-mL) bottle fits in 4-in.-diameter wells, and the two smaller bottles fit in 2-in.-diameter wells. The VOA vials can be used in common laboratory autosampler equipment, eliminating any need to transfer these samples.

Multiple bottles can be deployed in tandem on a single trigger line or on multiple trigger lines when different types of samples need to be collected or when larger sample volumes are required. Up to six Snap Samplers can be deployed in tandem on a single trigger line, depending upon the type of trigger mechanism. The types of trigger mechanism include mechanical, electronic, and pneumatic. Electronic or pneumatic trigger devices are needed for deeper wells or for deploying larger numbers of samplers on a single trigger line.

\subsection{TECHNOLOGY DEVELOPMENT}

Several studies by independent researchers have evaluated the performance of this sampler. Parsons, Inc. (2005) conducted a field study at the former McClellan AFB that evaluated six different passive samplers, including the Snap Sampler. In this study, analyte concentrations in samples taken with the various passive samplers were compared with analyte concentrations in samples that were taken using two pumped sampling methods, low-flow purging and sampling and well-volume purging and sampling (where the well was purged of three to five well volumes and then a sample was collected using a bailer). For the Snap Sampler, analytes that were compared included several VOCs (including 1,4-dioxane) and anions. While this work has not been published in a peer-reviewed journal, the final report is available on-line.

Interpreting the results from this study is difficult for several reasons, including differences in the sampling day and sample handling (some VOC samples were poured into a second container while others were not). Also, the data for the various analytes were pooled prior to conducting the statistical analyses. However, regression plots of the pooled VOC data were informative. The Snap Sampler VOC concentrations correlated well with those taken using low-flow purging and sampling, although they were higher (with a slope of 1.77). In contrast, a similar comparison of the Snap Sampler and three-well-volume samples indicated that the concentrations of VOCs agreed well (with a slope of 1.04). The findings were similar for the anions. There could be several reasons why VOC concentrations would be lower in the low-flow samples including 1) the Grundfos pump used for the low-flow samples could have caused losses of VOCs by heating the well water, and 2) new LDPE tubing was used to collect the low-flow samples, which would cause some losses of VOCs due to sorption by the tubing (Parker and Ranney 1998). However, neither reason would explain why the anion concentrations were also lower in the low-flow samples.

Our laboratory has conducted both laboratory and field studies that have evaluated the ability of the Snap Sampler to recover representative concentrations of VOCs and explosives in ground water (Parker and Mulherin 2007). The laboratory studies were conducted in a large (244-cm or 8-ft tall, 20-cm or 8-in. diameter) polyvinyl chloride (PVC) standpipe that contained known concentrations of either a suite of VOCs or explosives. Analysis of the data revealed that the Snap Sampler recovered comparable concentrations of VOCs after a 3-day equilibration period and of explosives after 24 hours. 
In our field studies (Parker and Mulherin 2007), we evaluated the ability of this sampler to recover equivalent concentrations of VOCs and explosive compounds when compared with the EPA's low-flow purging and sampling method (USEPA Region 1, 1996). Field sites included our own laboratory (ERDC-CRREL in Hanover, NH), the Silresim Superfund site in Lowell, MA, and the former Louisiana Army Ammunition Plant (LAAP) in Minden, LA. At CRREL, one of our wells contaminated with trichlorethylene (TCE) was sampled using both sampling methods on 5 different days. At the Silresim site, four wells were sampled for 13 VOCs that included BTEX compounds and several chlorinated VOCs. At LAAP, five wells were sampled for seven explosive compounds and their daughter products.

The results of the statistical analyses of the data from all the sites indicated that there were no statistically significant differences between the concentrations of VOCs and explosives in the samples taken with the Snap Samplers vs. the low-flow samples.

\subsection{ADVANTAGES AND LIMITATIONS OF THE TECHNOLOGY}

Advantages of using the Snap Sampler include the following: it collects a whole-water sample that is sealed under in-situ conditions, it can be used to collect a sample at a discrete depth in the well, samples do not require additional transfer to another container after collection, there is no purge water generated that requires disposal, and there are no power requirements. Because samples remain in the original bottle in which they were collected, presumably losses of volatiles and changes in concentrations of dissolved gases or analytes subject to oxidation/precipitation reactions (which can occur during transfer) are reduced. Also, because the sample is sealed at the sampling depth in the well, concerns about contamination of the sample from the upper cased portion of the well as the sampler is removed from the well are eliminated.

Because the Snap Sampler is deployed prior to sampling to allow the well to recover from any disturbance associated with placing it in the well and because this device collects a whole-water sample instantaneously, presumably samples should not have elevated turbidity (i.e., soil-derived, non-transportable particles) and thus should reflect the true, naturally mobile, colloid-borne contaminants flowing through the well. In contrast, even low-flow sampling has been shown to artificially elevate particle levels in some wells (Bailey et al. 2005), and most diffusion samplers cannot collect colloidal particles because of the small pore sizes of the membranes.

Previous studies by our laboratory (Parker and Ranney 1998) have demonstrated that when lowflow purging and sampling is used, sorption by longer lengths of (non-equilibrated) polymer tubing can substantially reduce concentrations of some VOCs. In contrast, there are no losses of these analytes in samples collected with the Snap Sampler when it has been equilibrated before collection (Parker and Mulherin 2007). However, there is a primary distinction between lowflow purging and sampling and using the Snap Sampler-the Snap Sampler can be used to collect a sample at a discrete depth in the well, whereas the low-flowing sampling collects a sample that is a flow-weighted average over the screened interval.

One final advantage of the Snap Sampler is that it can be used to sample wells with slow recharge. In contrast, any purging method that removes all the water from the well will yield suspect samples, especially for volatiles and analytes subject to oxidation/precipitation reactions. 
The principal limitations of this technology are well diameter and sample volume. The 40-mL VOA vials and 125-mL HDPE bottles do not fit in wells smaller than 2-in. diameter, and the larger 350-mL bottle does not fit in wells that are smaller than 4-in. diameter. While multiple samplers are used to collect more samples or a larger sample volume, they increase the length of the sampling interval.

While, in many respects, the HydraSleeve is a similar passive sampling device (i.e., it can be used to collect a whole-water sample and can be used to sample for a broad spectrum of analyte types), the integrity of the sample depends on when the reed valve closes. According to the manufacturer, an interval that is about 1.5 times the length of the sampler is needed to completely fill the device. Also, there is no need to transfer the sample at the well head with the Snap Sampler as there is with the HydraSleeve. 


\subsection{DEMONSTRATION DESIGN}

\subsection{PERFORMANCE OBJECTIVES}

The primary objectives for this demonstration/validation project were to demonstrate that the Snap Sampler passive ground water sampling technology can provide 1) technically defensible analytical data for a number of VOCs and inorganic analytes and 2) substantial cost savings. A generalized list of the specific performance objectives used to evaluate the Snap Sampler and RGC sampler is given in Table 3-1.

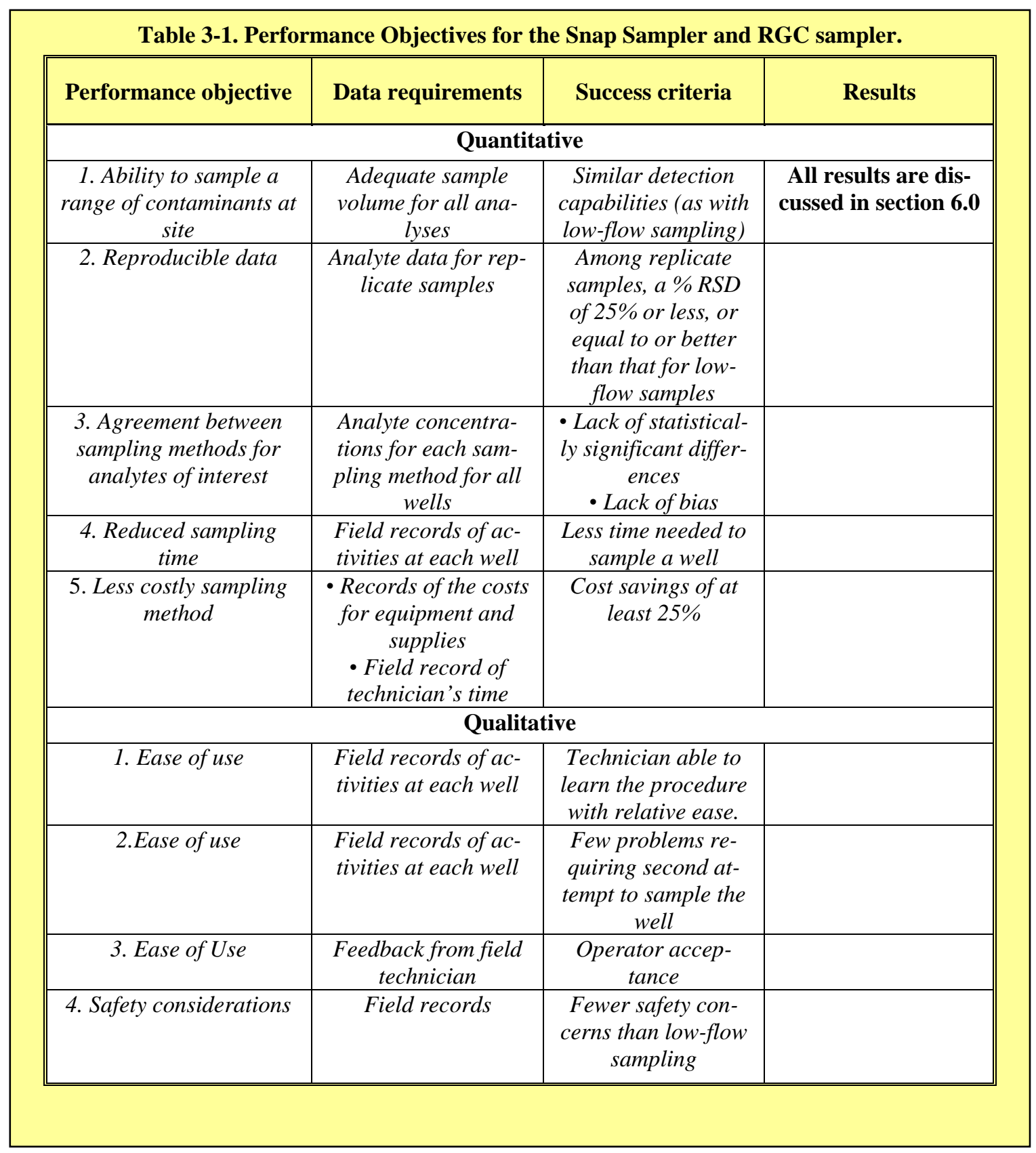




\subsection{PROOF-OF-CONCEPT STUDIES FOR INORGANIC ANALYTES}

Before we conducted this demonstration project, there had been no laboratory studies that examined the ability of the Snap Sampler to recover inorganic analytes. So, prior to any field work, laboratory studies (Parker et al. 2008, 2009) were conducted as part of this project to determine whether this sampler could recover representative concentrations of a suite of inorganic analytes. These tests were conducted at room temperature in a standpipe (as described previously) that contained test solutions with known concentrations of a suite of inorganic analytes. Analytes included both cations (Ca, Cd, $\mathrm{K}, \mathrm{Mg}, \mathrm{Mn}$, and $\mathrm{Na}$ ) and anions ( $\mathrm{As}, \mathrm{Br}, \mathrm{Cl}, \mathrm{Cr}$, nitrate, perchlorate, and sulfate). Analysis of the data revealed that the Snap Sampler recovered comparable concentrations (i.e., >99\% recovery) of all the analytes following a brief (48-hour) equilibration period. Precision among the replicate samples was excellent, with the relative standard deviation generally less than $2 \%$.

\subsection{ABILITY TO YIELD QUALITY DATA}

The most important objective was to determine if these passive sampling methods, especially the Snap Sampler, yielded quality, defensible data. There are several ways to determine this. First, the sampling method must provide adequate sample volume for the analyses so that the detection capabilities (or sensitivity) of the sampling method is similar to that of low-flow sampling. The most stringent test of this was at the McClellan site, where samples were collected for several analyte types, and the needed sample volume was the greatest.

To evaluate whether the passive methods could yield data that are reproducible, we set the following guideline (for the data at the McClellan site): the Relative Standard Deviation (RSD) should be either 1) $25 \%$ or less, or 2) equal to, or better than, that for low-flow samples (for analytes where the concentrations were greater than or equal to three times the reporting limit).

Also, there should be good agreement between analyte concentrations for the passive and lowflow sampling methods. Equivalency can be determined by a lack of statistically significant differences between the two methods using standard statistical analyses. Good agreement between the sampling methods can also be determined by seeing if there is a lack of bias between the lowflow and each of the passive sampling methods. A lack of bias can be determined by using a linear regression of the passive sampler data vs. the low-flow data to see if the slope of the line is significantly different from 1.0. A slope of 1.0 indicates that there is no significant bias between the two data sets, i.e., there is a one to one correlation between the concentrations for the two methods.

\subsection{LESS COSTLY SAMPLING METHOD}

The other primary objective of this demonstration was that the sampling method be less costly than low-flow purging and sampling. This objective included two quantitative performance objectives: 1 ) to reduce sampling time and 2) to reduce sampling costs by $25 \%$. To find out whether these criteria were met, accurate records of all the expenses associated with the equipment and supplies and of the field crew's time had to be kept for each of the sampling methods at each of the sites. Records included set-up time, sampling time, sample processing time, and time for site clean-up. 


\subsection{EASE OF USE}

Another measure of the performance of the passive samplers included ease of use, which was more qualitative. Criteria used to determine the ease-of-use included: 1) could the technician learn the procedure relatively easily, 2) were there few problems that resulted in the well having to be sampled more than once, and 3) did the operator, in general, accept the method. The first two of these criteria were determined from sampling records in the field notebook. Operator acceptance was determined from feedback by the field technician. The relative safety of the three sampling methods was also compared. 


\subsection{SITE DESCRIPTIONS}

\subsection{FORMER PEASE AFB}

\subsubsection{Location}

The former Pease AFB occupies approximately 4365 acres and is located on a peninsula in southeastern New Hampshire (Fig. 4-1), in the town of Newington and the City of Portsmouth. The peninsula is bounded on the west and southwest by Great Bay, on the northwest by Little Bay, and on the north and northeast by the Piscataqua River.

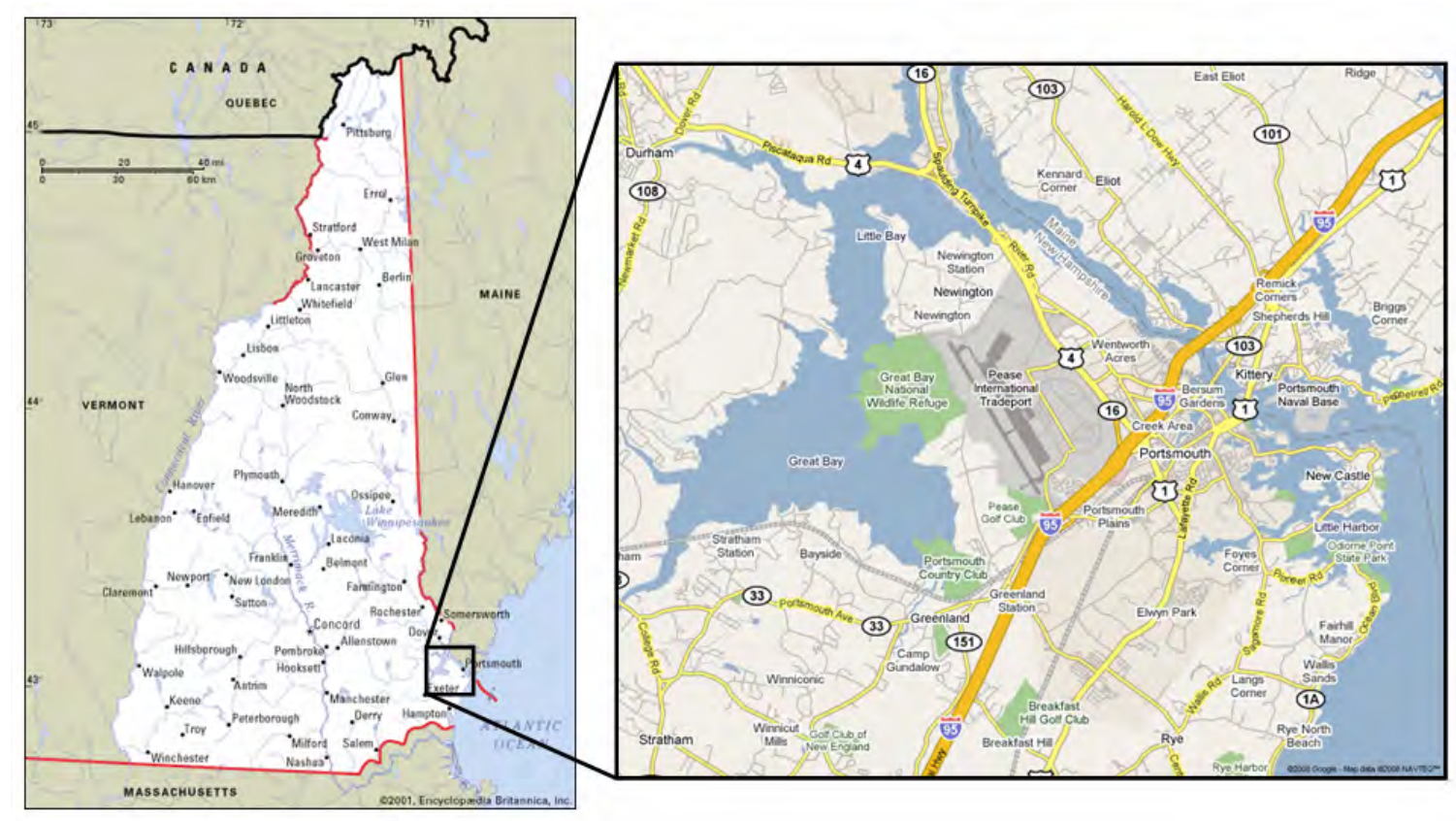

Figure 4-1. Location of the former Pease AFB.

\subsubsection{Site Geology/Hydrogeology}

The eight monitoring wells selected for this demonstration were located in two of the eight installation restoration plan zones established in 1991, specifically in Zones 1 and 3. Zone 1 is located in the eastern part of the former base. Zone 3 encompasses the area where most of the industrial shops and aircraft maintenance were located.

Descriptions of the geology of these zones were taken from the 5-year review published in 2004 (MWH Americas, Inc. 2004). The unconsolidated stratigraphic units identified at Pease AFB are fill, Upper Sand (US), Marine Clay and Silt (MCS), Lower Sand (LS), and glacial till (GT). One or more of these units may be absent at any particular location.

\subsubsection{Zone 1}

Zone 1 includes six areas of concern: four landfills (LF-2, LF-3, LF-4, and LF-5), the Bulk Fuel Storage Area (BFSA), and the Paint Can Disposal Area (PCDA). The BFSA consists of a 16acre parcel and is where two wells (3-5045 and 13-6095) were located. 
The overburden deposits across Zone 1 include younger sediments, such as marsh deposits, and older deposits, such as glacial-marine deposits. Across this zone, the thickness of the US unit ranges from approximately 0.6 to $10 \mathrm{ft}$, and the LS unit is absent. Both the MCS and GT units are discontinuous and often not present across the zone, in part because of excavation and removal. This has resulted in hydraulically interconnected bedrock and overburden water-bearing zones in much of this area.

The topography of the bedrock surface is accentuated by several prominent heights and one prominent valley, with up to $75 \mathrm{ft}$ of relief zone-wide. The bedrock consists of rocks of the Eliot Formation, which is generally composed of interbedded phyllite, metagraywacke, and quartzite.

The following information on the hydrogeology of Zone 1 was taken from Roy F. Weston, Inc. (1993). There are two water-bearing units in this zone. A shallow water table unit is present in the thin overburden and shallow bedrock. Because much of the overburden is unsaturated, the first water encountered is often in the shallow bedrock, referred to as the water table aquifer. A second water bearing unit is located in the deep bedrock.

Within the water table aquifer, most of the groundwater is characterized by unconfined conditions between the overburden and shallow bedrock. Groundwater flow within this zone is radially away from a recharge area located in the vicinity of the southwest corner of the BFSA and PCDA. Two significant groundwater divides exist in the water table across this zone. A northeast-southwest trending groundwater divide exists through a portion of the BFSA, and hydraulically separates the PCDA/LF-5 from the BFSA. A second north-south trending divide in the vicinity of LF-5 results in eastward and westward components of flow. Discharge of the water table unit in this area is to Flagstone Brook and the Railway Ditch. Groundwater velocity in the water table aquifer ranges from $0.013 \mathrm{ft} /$ day to $4.56 \mathrm{ft} /$ day. Well 3-5045 was located within this unit, and the approximate depth to groundwater was $3 \mathrm{ft}$ below ground surface (bgs).

Groundwater flow in the deep bedrock generally parallels that in the water table aquifer. The groundwater velocity in the deep bedrock unit ranges from 4.3 to $257 \mathrm{ft} /$ day. Well 13-6095 was within this unit, and the approximate depth to ground water was $6 \mathrm{ft}$ bgs.

\subsubsection{Zone 3}

Zone 3 is located in the central portion of the former AFB and occupies approximately 440 acres. Six of the wells used in this demonstration were located at site 32 in this zone. The depth to groundwater for the wells used in this study ranged from 3 to $7 \mathrm{ft}$ bgs, and all the well screens were fully submerged below the water table.

The shallow subsurface beneath this zone generally consists of the same lithologic units mentioned previously. The MCS behaves as an aquitard in the area around site 32, and the LS and GT units are treated as a single hydrostratigraphic unit because of their textural and hydrological similarities (Roy F. Weston, Inc. 1995). The water table occurs within the US at depths of 0 to 6 $\mathrm{ft}$ bgs. Regional groundwater flow is generally to the east within each of the water bearing units at site 32, and the average velocity of the groundwater in the LS/GT unit is $0.0016 \mathrm{ft} /$ day (with a maximum of $0.004 \mathrm{ft} /$ day) (Roy F. Weston, Inc. 1995). 
The underlying bedrock at site 32 is the Kittery formation, and consists of dark gray to dark green phyllite interbedded with fine- to medium-grained, finely laminated to thinly bedded biotitic quartzite. The thickness of the overlying, unconsolidated lithological units varies across the site as the elevation of the bedrock interface is highly variable. Cross-sections of the stratigraphy of this zone can be found in Parker et al. (2009) and are characteristic of the stratigraphy of the entire site. The top $20 \mathrm{ft}$ of bedrock at site 32 is relatively highly fractured. The transition zone from relatively high- to low-density fracturing (and corresponding well yields) is highly variable throughout this zone, but ranges from 25 to $100 \mathrm{ft}$ below the bedrock surface (Roy F. Weston, Inc. 1995). At site 32, the average flow velocity in the shallow fractured bedrock was $2.04 \mathrm{ft} / \mathrm{day}$ (with a maximum of $3.9 \mathrm{ft} /$ day), and the average flow velocity in the deep competent bedrock was $0.03 \mathrm{ft} /$ day (with a maximum of $0.085 \mathrm{ft} /$ day) (Roy F. Weston, Inc. 1995). Both upward and downward hydraulic gradients near buildings 113 and 119 suggest that fractured bedrock seasonally receives recharge from the LS unit and discharges to the east-northeast down-gradient of these buildings, and that the shallow bedrock receives groundwater from the deep, competent bedrock between building 113 and Portsmouth Avenue (Roy F. Weston, Inc. 1995).

\subsubsection{Contaminant Distribution}

Over time, various quantities of fuels, oils, lubricants, solvents, and protective coatings were used at this site, and as a result, contaminants from these substances were released into the environment. Specifically, fuels, organic solvents, polycyclic aromatic hydrocarbons (PAHs), and metals have been found in soils on the base. The groundwater has been found to be contaminated with volatile organic compounds (VOCs), including trichloroethylene (TCE) and tetrachloroethylene (PCE). PAHs, pesticides, and heavy metals have been found in the sediments from various discharge ditches. (No map of the groundwater contaminant plumes is provided because the focus of the demonstration was on inorganic analytes.)

\subsection{FORMER McCLELLAN AFB}

\subsubsection{Site Location}

The former McClellan AFB is located approximately 7 miles northeast of downtown Sacramento, California and occupies approximately 2952 acres (Fig. 4-2). The former base includes 107 maintenance buildings and 200 shops.

\subsubsection{Site Geology/Hydrogeology}

\subsubsection{Geology}

The former McClellan AFB is located in the Central Valley, which extends approximately 120 miles north to Redding and about 400 miles south to Bakersfield, and is approximately 40 miles wide. The valley is bordered by the Sierra Nevada range on the east and the mountains of the Coastal Ranges on the west. It is divided into the Sacramento Valley (north of the confluence of the Sacramento and San Joaquin Rivers) and the San Joaquin Valley (south of the confluence). 


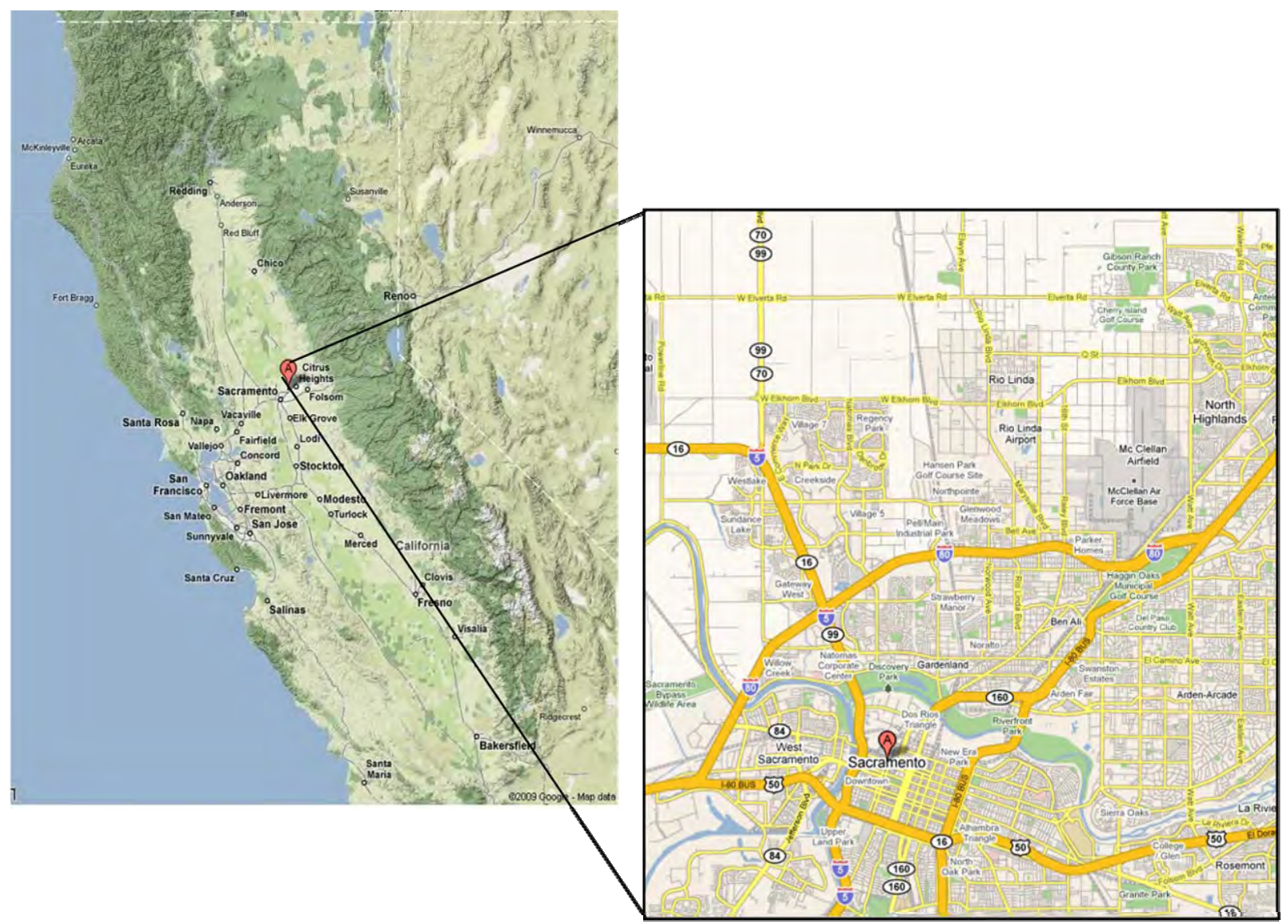

Figure 4-2. Former McClellan AFB (adapted from Google 2009).

The former base is located on an alluvial plain forming the eastern side of the Sacramento Valley. The plain is nearly flat, and is dissected by numerous westerly trending streams that drain the Sierra Nevada. The American and Sacramento Rivers are the major drainages for the area. The land surface gently slopes from east to west, exhibiting little topographic relief. Ground surface elevations range from approximately $75 \mathrm{ft}$ above mean sea level (amsl) on the eastern side to approximately $50 \mathrm{ft}$ amsl on the western side.

In general, the sediments in the upper few hundred feet of the subsurface consist of coalescing deposits laid down by alluvial and fluvial systems of various sizes and competence that flowed generally from northeast to southwest or west. Sediments are primarily sand, silt, and clay, generally poorly sorted, with localized occurrences of gravel in the southern part of the base. The nature of fluvial deposition produced morphologically irregular lenses and strata that are laterally and vertically discontinuous. The coalescing and intercalating nature of the sediments makes distinction among units (or stratigraphic correlation over distances greater than a few tens of feet) difficult. Individual lithologic units rarely extend laterally for more than $50 \mathrm{ft}$.

\subsubsection{Hydrogeology}

The aquifer system at the base has been divided into a series of monitoring zones that were defined based on stratigraphy derived from geophysical logs. They are designated A through F, from shallowest to deepest. The monitoring wells that were used in this demonstration are com- 
pleted in the $\mathrm{A}, \mathrm{B}$, or $\mathrm{C}$ zones. Zones $\mathrm{A}$ and $\mathrm{B}$ are younger and extremely heterogeneous, and were deposited by low energy fluvial deposits. Zone A typically extends from the ground surface down to approximately 50 to $75 \mathrm{ft}$ bgs. Zone A sediments have a lower permeability than the other zones, and the estimated flow seepage velocities in this zone range from 0.01 to $1.3 \mathrm{ft} / \mathrm{day}$ (Radian 1992). Zone B extends from the base of Zone A to approximately 125 to $140 \mathrm{ft}$ bgs, and the estimated flow seepage velocities range from 0.37 to $1.98 \mathrm{ft} / \mathrm{day}$. Zone C is older and consists of generally coarser grained sediments (sands and gravels) that were deposited by higher energy fluvial erosional deposits (CH2M Hill 1994). Zone C extends from the base of Zone B to approximately 200 to $240 \mathrm{ft}$ bgs. The estimated seepage velocities in Zone C range from 0.30 to 4.35 $\mathrm{ft} / \mathrm{day}$. (The highest estimated velocity reflects the steeper hydraulic gradient near one of the base wells.)

Prior to development and extensive groundwater use in the area, the water table was approximately 30 to $50 \mathrm{ft}$ bgs. However, because of extensive use, the water table has been dropping continually for the past 50 years and currently is between 90 to $110 \mathrm{ft}$ bgs. The general direction of groundwater movement beneath the base has also changed over the past century as groundwater use increased. Currently, groundwater flow is in a south to southwesterly direction, although the direction of groundwater movement locally is influenced by water-supply wells and by groundwater extraction and treatment systems (Radian 1992).

\subsubsection{Contaminant Distribution}

Trichloroethylene (TCE), tetrachloroethylene (PCE), cis-1,2-dichloroethylene (cDCE), 1,1dichloroethylene (DCE), and carbon tetrachloride are the predominant contaminants of concern (COC) in groundwater but there were eight other VOCs with reported concentrations above maximum contaminant levels (MCLs). Although, there are numerous source areas there are three primary areas with VOC groundwater contamination: 1) west side of the airfield, 2) east side of airfield, and 3) and an isolated area northeast of the airfield. The source terms on the east and west portion of the base have coalesced into two broad areas of contamination with the plumes extending southward (Fig. 4-3). The contaminant having the greatest spatial extent is TCE, which underlies approximately 520 acres (18\%) of the base and an additional 70 acres off-base. Contamination is principally confined to the uppermost groundwater zones, but has been detected at $390 \mathrm{ft}$ (CH2M Hill 1994). 


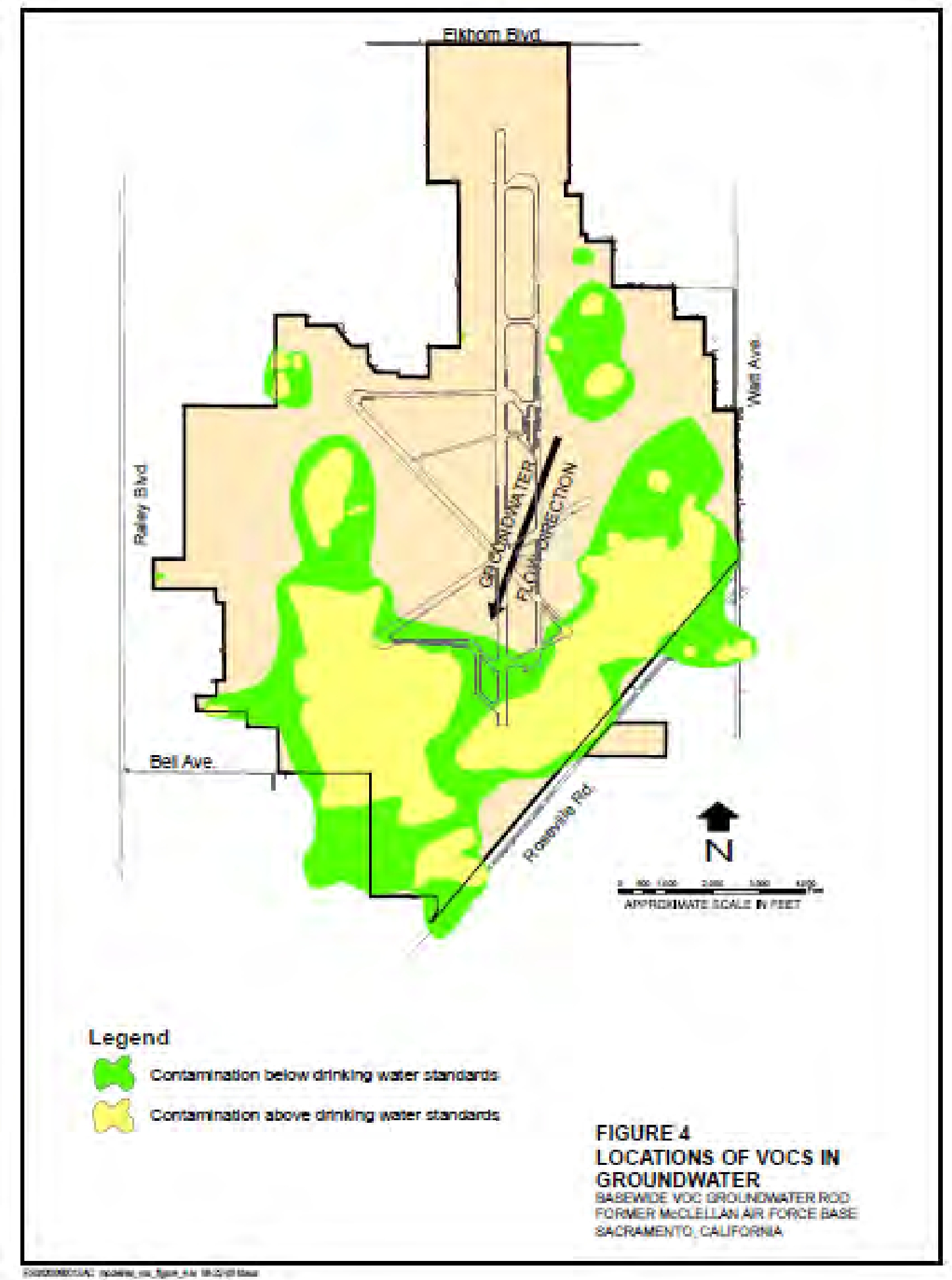

Figure 4-3. Extent of volatile organic compound contamination in groundwater at McClellan Air Force Base (adapted from Parsons 2004). 


\subsection{TEST DESIGN}

At both sites, there were 10 sampling events. At both sites, each of the monitoring wells were sampled using 1) Snap Samplers, 2) low-flow purging and sampling (US EPA Region 1, 1996), and 3) RGC samplers.

\subsection{FORMER PEASE AFB SITE}

\subsubsection{Conceptual Experimental Design}

Eight 4-in.-diameter groundwater monitoring wells were selected for use at this site. Two of the wells were sampled twice so that there was a total of 10 sampling events. The historical depth to water in these wells ranged from 3 to $7 \mathrm{ft}$ bgs. The top of the screen ranged from 11 to $45 \mathrm{ft}$ bgs. Screen lengths varied from 5 to $15 \mathrm{ft}$. In all cases the screens were full submerged. Six of the wells were constructed with PVC casings and screen, and two of the wells were stainless steel wells. Analytes of interest at this site included: As, Ca, Fe, Mg, Mn, K, and Na.

For the statistical analyses and the subsequent interpretation of the results to be as robust and accurate as possible, it was important to minimize any extraneous factors that could influence the data quality. Therefore, we included the following provisions in the design of this demonstration.

1. Redeveloping wells with heavy sediment loads.

2. Selecting wells with known detectable concentrations of constituents of concern.

3. Determining the flow pattern in each of the wells.

4. Matching sampling depth for each sampler with the pump intake for low-flow sampling.

5. Carefully selecting a sampling order that reduces sampler impacts on subsequent sampling events.

\subsubsection{Baseline Characterization}

Prior to field demonstration, several activities were conducted. These included well development, determining the flow patterns in the wells by conducting flow-meter testing, profiling analyte concentrations in the wells with depth, initial low-flow sampling, and blank tests on the equipment.

\subsubsection{Well Development}

Preliminary assessment of the wells revealed that most had large amounts of silt in them. As it was important that the wells function properly and not contain large sediment loads that could easily be disturbed, we redeveloped all of them using a surge-and-purge technique. However, we were not able to obtain clear water in three of the eight wells. Specifically, substantial turbidity remained in wells 32-5020 and 32-6135, and there was slight turbidity in water from well 136095.

\subsubsection{Flow Meter Testing}

Once the wells were redeveloped, the flow pattern in each well was determined by using a heatpulse flow meter. These tests were conducted under both static and low-flow pumping conditions. Additional information on this sampling technology and the field methods used in this study can be found in Parker et al. (2009). 


\subsubsection{Ambient Vertical Flow Testing}

Ambient (non-pumping) flow test data indicated that there was measurable vertical flow in only one of the eight wells, well 32-5031. However, the velocity of the flow in this well was slight (0.01 gal./minute) and was in a negative direction, indicating a slight downward vertical flow in this well.

\subsubsection{Dynamic Vertical Flow Testing}

More detailed findings from the flowmeter testing under low-flow pumping can be found in Parker et al. (2009). The measurements indicated a variety of flow patterns in the test wells. Some wells showed nearly equivalent contributions from the top and bottom portions (e.g., wells 32-5020 and 32-6135). Three of the four bedrock wells showed a significant contribution from one portion of the screened interval under pumped conditions. Specifically, wells 32-6008 and 32-6064 showed significant contributions from the upper zone, and well 13-6095 showed significant contribution from the deeper portion of the well.

\subsubsection{Profiling Contaminant Stratification with Depth in the Wells}

To profile possible stratification of the analytes with depth in the wells, two Snap Samplers with its own trigger line and baffle were deployed in each well. The baffles were used to separate the upper and lower zones and to separate the screen from the blank casing. Both samplers were placed in the middle of their respective zones. The samplers were left in the well for one week before collection. Additional details on the methods used and the data from this testing can be found in Parker et al. (2009).

For most of the wells, there was no substantial difference between the analyte concentrations in the sample collected from the shallow vs. the deeper portion of the well. The most notable exception was well 32-5020, where concentrations of the analytes (except $\mathrm{Na}$ ) were higher in the deeper portion of the well. However, this difference was believed to be caused by the heavier sediment load found in the deeper sample. This is one of the wells we were not able to successfully redevelop. We suspect that the filter pack or screen for this well, or both, may not have been correctly sized and, thus, the filter pack or screen were not able to prevent fines from entering the well. Two of the bedrock wells (32-6064 and 13-6095) also showed slightly higher concentrations of As and Fe in the shallow portions of the wells.

\subsubsection{Equipment Blanks}

Prior to deploying the bladder pumps and other sampling equipment in the wells, equipment blanks were drawn for the bladder pumps, Snap Samplers, and the RGC samplers. This testing was conducted in our laboratory and details on the sampling methods can be found in Parker et al. (2009). Generally, concentrations for the blank samples indicated that leaching of constituents from the test equipment was not a concern.

\subsubsection{Initial Low-Flow Sampling of the Wells}

Preliminary unfiltered low-flow samples were collected from all the wells using the EPA's lowflow purging and sampling protocol. This was done for four reasons: 1) to determine the initial analyte concentrations, 2) to confirm the flow rate to be used would not cause excessive drawdown in the wells, 3 ) to determine the sampling time for low-flow sampling (needed for the cost analyses), and 4) to give the materials in the pump and tubing time to equilibrate with the ana- 
lytes in the well water (to reduce possible losses from sorption). The detailed results of the initial low-flow sampling can be found in Parker et al. (2009).

\subsubsection{Field Testing}

\subsubsection{Sampling Equipment}

For this study, a small (3/4-in.-diameter) bladder pump with Teflon-lined polyethylene (PE) tubing was used in each well. The Snap Sampler equipment included: 40-mL glass Snap Sampler VOA vials, 125-mL Polypropylene (PP) Snap Sampler bottles, acetal (Delrin) plastic Snap Sampler bodies, and conventional trigger lines with mechanical trigger mechanisms.

Pre-cleaned regenerated cellulose (CelluSep H1) membrane in preservative solution was purchased for this study. The average pore size for this membrane is $0.0018 \mu \mathrm{m}$. The tubing that was placed inside the membrane for support of the samplers was PP tubing, and the outer protective mesh was black low-density PE (LDPE). The RGC samplers were constructed just prior to leaving for the field site and were stored on ice in PE bags containing deionized, distilled (DI) water. The samplers were sparged overnight with nitrogen gas prior to deployment in the wells. More details on the construction and handling of these devices can be found in Parker et al. (2009).

The baffles consisted of two circular discs of 0.030-in.-thick PE, sized slightly larger than the inside diameter of the well. Around the outside of the disc, slits were cut to allow the baffles to deform slightly so that the baffle fit tightly within the well. The slits in the two discs were misaligned to limit water exchange between the two zones.

\subsubsection{Deployment of Sampling Equipment}

The bladder pump was placed at approximately the midpoint of the well screen. The two Snap Samplers were deployed in tandem on the same trigger line, one just above the pump intake and one just below the intake of the pump (Fig. 5-1). The RGC sampler was deployed at the same depth in the well as the pump intake. The baffle was positioned $0.5 \mathrm{ft}$ above the top of the well screen. A 1-L plastic water bottle filled with sand was added to the string of samplers and was used as a weight to facilitate deployment of the equipment in the well.

The samplers were left to equilibrate in the well for at least 2 weeks prior to sampling. Two weeks is more than enough time for the materials in the RGC samplers and Snap Samplers to equilibrate with the analytes in the well water (and thus prevent losses from sorption) and also gives the well time to recover from any disturbance caused by placing the samplers in most wells, except for wells in fine-grained materials, fractured rock, shale, etc. (Vroblesky 2001; Halevy et al. 1967). For the RGC sampler, equilibration of VOCs occurs in 3 days or fewer and in 7 days or fewer for inorganics (ITRC 2007). For the Snap Sampler, equilibration occurs within 4 days for most VOCs (Parker and Mulherin 2007) and within 2 days for inorganic analytes (Parker et al. 2008, 2009). While low-flow sampling equipment (i.e., pump and tubing) and the Snap Sampler can be left in the well for an extended period (e.g., months), it may not be feasible to leave RGC samplers in the well for extended equilibration times because the membrane can undergo biodegradation. 


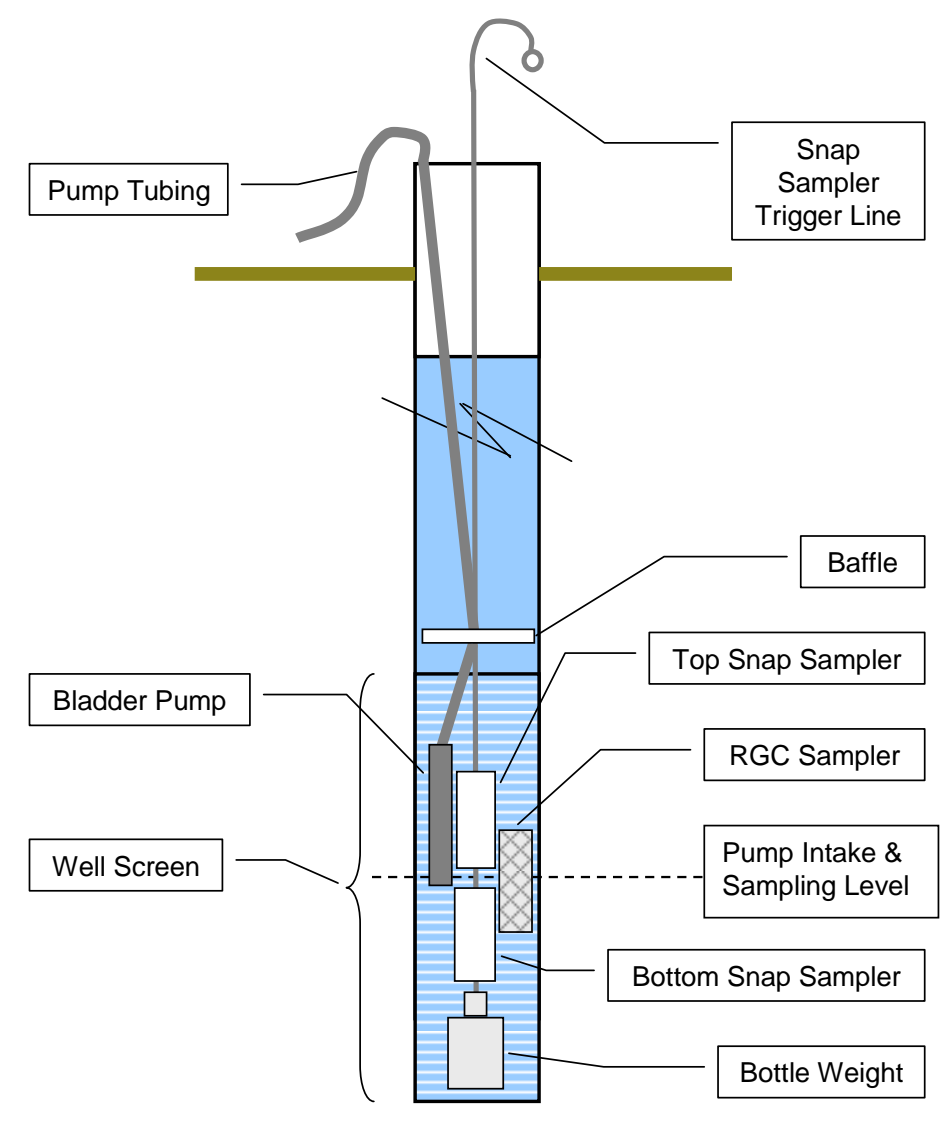

Figure 5-1. Deployment of sampling equipment in each well.

\subsubsection{Sampling Methods}

\subsubsection{Sample Collection and Handling}

Each of the eight wells was sampled using the three sampling methods. A second round of sampling was conducted using two of the original eight wells to yield a total of 10 sampling events. Samples were collected for total analyte analyses using low-flow sampling and the Snap Sampler, and all three sampling methods were used to collect samples for dissolved analyte analyses.

In addition, standard QA/QC samples were collected. These included field duplicates, trip blanks, and duplicates for (laboratory) spiked recoveries to determine matrix effects (i.e., Matrix-Spike samples [MS] and duplicate Matrix-Spike samples [MSD]). Filter blanks were tested in the laboratory.

The following sampling order was used for most of the sampling events: 1) the Snap Sampler was triggered, 2) the low-flow samples were collected, 3) the equipment was removed from the well and an aliquot from the RGC sampler was transferred to a sample bottle, and 4) the sample bottles were removed from the Snap Sampler. 


\subsubsection{Sample Analyses}

Samples that were to be analyzed for dissolved constituents were filtered in the laboratory and unfiltered samples were digested using nitric acid. Analyses were conducted using Inductively Coupled Plasma /Mass Spectrometry (ICP/MS) using EPA Method 200.8 (Creed et al. 1994) according to EPA SW 846 method 6020B (USEPA 1996). All samples were analyzed within the specified holding times.

\subsubsection{Statistical Analyses}

For the statistical analyses, concentration data were analyzed on an analyte-by-analyte basis; data for total and dissolved concentrations of each analyte were treated separately.

Standard statistical analyses were used to analyze the data. The data sets were first analyzed to determine if they were normally distributed and if the variances were homogenous. Whenever possible, conventional parametric analyses were used. In instances where conventional parametric tests could not be used, non-parametric (ranked) tests were used. When parametric analyses could be used, a Repeated Measures Analysis of Variance (RM-ANOVA) test with the Holm Sidak method for pair-wise multiple comparisons was used to determine if there were significant differences between the sampling methods. In cases where non-parametric analyses had to be used, the Friedman RM-ANOVA on Ranks test with the Tukey test were used.

\subsubsection{Sampling Results}

Inorganic analytes at this site included a metalloid (As), and several metals including alkali metals (sodium [Na] and potassium [K]); alkaline earth metals (magnesium [Mg] and calcium [Ca]); and transition metals (manganese [Mn], and iron [Fe]). Statistical analyses revealed that the Snap Sampler generally recovered samples with equivalent concentrations of inorganic analytes to those found using the EPA's low-flow purging and sampling protocol. This was true for both filtered and unfiltered samples, with the exception of the total Fe samples. For each analyte, linear regression analyses of the Snap Sampler data vs. low-flow data generally showed a strong correlation, with the slope of the line not significantly different from 1.0 in most instances. A typical example is given for total $\mathrm{Mg}$ in Figure 5-2. In contrast, the results for total Fe are shown in Figure 5-3.

We believe that the elevated Fe was the result of the elevated turbidity in some wells. In some cases, we believe that the elevated turbidity was the result of well-construction practices or possibly degradation of the stainless steel screen. However, for most of the wells, the elevated concentrations of unfiltered Fe appeared to be the direct result of the disturbance of the well that was caused when all the equipment (including the pump, RGC and Snap samplers, and baffle) was installed (simultaneously) in the well. In some wells, we observed that there actually was a sucking sound as the equipment fell into place within the water column. Although we did not measure the turbidity in the Snap Sampler samples, the initial turbidity values at the start of low-flow sampling indicated that, generally, turbidity was considerably higher in this sampling event than it had been during the preliminary round of sampling. This supports our hypothesis that deploying all this equipment in the well elevated the turbidity. 


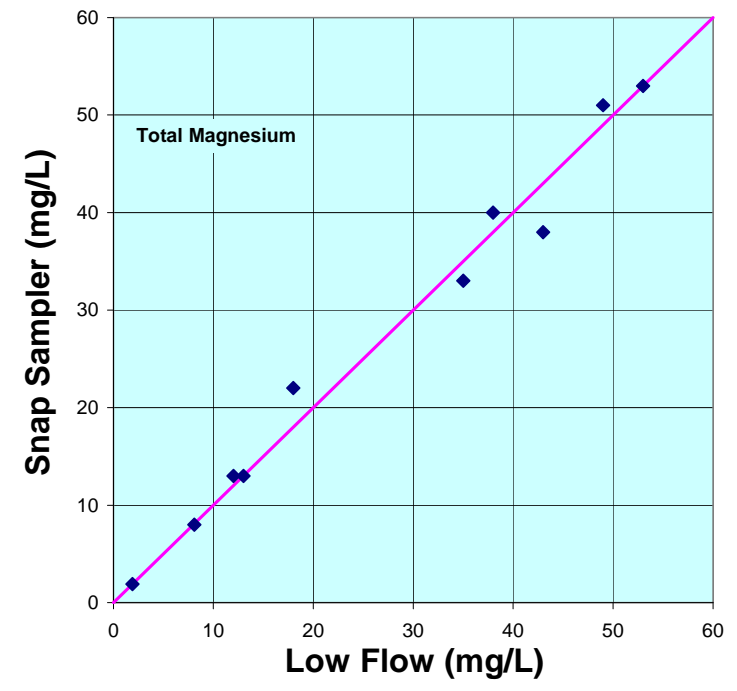

Figure 5-2. Linear plot of the Snap Sampler and low-flow data for total Mg.

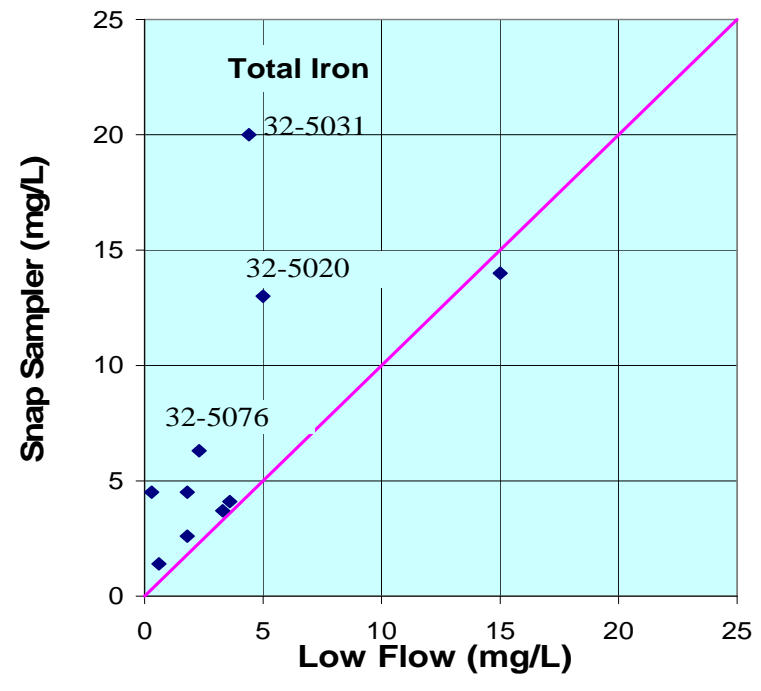

Figure 5-3. Linear plot of the Snap Sampler and low-flow data for total Fe.

The RGC sampler also provided samples with equivalent concentrations of these inorganic analytes when compared with unfiltered low-flow samples. The use of the RGC sampler in conjunction with low-flow sampling and the Snap Sampler demonstrated that colloidal transport of these analytes was not predominant at this site. This can also be seen by comparing the analyte concentrations of the filtered vs. unfiltered samples in the Snap Sampler samples. An example of this can be seen in Figure 5-4 that shows the dissolved (filtered) vs. total concentrations of Mg.

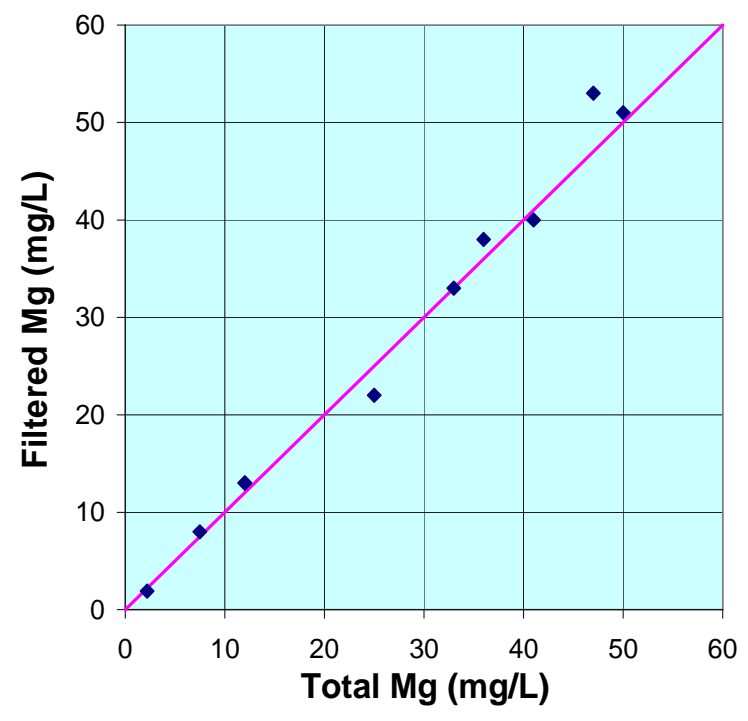

Figure 5-4. Plot comparing concentrations of total and dissolved $\mathrm{Mg}$ in the Snap Sampler samples. 


\subsubsection{Well-by-Well Comparisons using Unfiltered Sample Data}

While the statistical analyses clearly indicated that there was no consistent (significant) bias associated with using the Snap Sampler when compared with low-flow purging and sampling (for any of the analytes except unfiltered iron), we also examined the unfiltered data, well-by-well, to see if there were any wells where there appeared to be a large difference in the results for the different sampling methods.

The wells with the poorest agreement between the concentrations in the unfiltered samples taken with the Snap Sampler vs. low-flow sampling were numbers 32-6135 and 32-5031. For well 326135, the concentrations of Fe and Mn in the Snap Sampler were approximately 10 and 5 times higher (respectively) than the low-flow sample. For Well 32-5031, concentrations of As, Fe, and Mn in the Snap Sampler samples were 2, 5, and 3 times higher than the low-flow sample. Both of these wells were stainless steel; the other six wells had PVC casing and screen. Although we might expect Fe and Mn concentrations to be higher in stainless steel wells as a result of leaching (Parker et al. 1990; Hewitt 1989, 1992, 1994), arsenic is not a component of stainless steel so there is no reason to expect elevated concentrations of this analyte in these wells.

Thus, we suspect that much of these elevated concentrations of analytes resulted from higher turbidities in these wells. Higher turbidities may be the result of 1) installation of all the sampling equipment in the well (including baffles and bottle weights), which clearly agitated some wells and could cause oxidation/precipitation reactions, 2) poor well-construction design or installation methods, or 3) from degradation (corrosion) of the well screens, resulting in an increased slot size.

We were not able to successfully redevelop one of the wells, indicating that either poor well construction or design or degradation (i.e., corrosion) of the screen was the root cause.

In contrast, the other well appeared to have been dramatically affected by the installation of all the equipment in the well; the initial low-flow turbidity reading for this well was 35 times higher in this sampling event than it was in the preliminary sampling round (where only the pump was present in the well). As mentioned previously, agitating the well can result in coprecipitation of As, which would explain the elevated concentration of this analyte in this well.

There were other wells where there were elevated Fe levels, although concentrations were not elevated to the extent found in the previous wells. These wells also appeared to have been affected by the installation of the sampling equipment in the well, as the initial turbidity reading for these sampling events were 2 to 10 times higher than during the preliminary sampling round.

In contrast to the occasionally higher concentrations of other analytes found in the Snap Sampler, lower concentrations of total $\mathrm{Na}$ (by about $1 / 2$ ) were found in the Snap Sampler samples collected from theses two wells. This may be because low-flow pumping brought in more saline water from the surrounding estuary. These were the two shallowest wells. 


\subsection{FORMER MCCLELLAN AFB SITE}

\subsubsection{Conceptual Experimental Design}

Ten groundwater monitoring wells were sampled at this site. Analytes that were found at this site included VOCs and several inorganic analytes, including metals and some anions. Specifically, the VOCs at this site included TCE and various daughter products and MTBE. Metals and metalloids that were found at this site included $\mathrm{Al}$, As, $\mathrm{Ba}, \mathrm{Ca}, \mathrm{Cr}, \mathrm{Co}, \mathrm{Cu}, \mathrm{Fe}, \mathrm{Mg}, \mathrm{Mn}, \mathrm{Mo}, \mathrm{Ni}, \mathrm{K}, \mathrm{Na}$, $\mathrm{V}$, and Zn. Other anions that were found at this site included sulfate and chloride.

This demonstration differed from previous studies by our laboratory in that it was the first time our laboratory collected samples for several types of analytes using the Snap Sampler.

We made the following provisions in the design of this demonstration in an effort to reduce possible interferences with the statistical analyses of the data and interpretation of the findings:

- Selecting wells that were currently part of an active monitoring network, reducing the possibility of poorly functioning wells.

- Selecting wells with known detectable concentrations of constituents of concern.

- Selecting wells with historical data that indicated little if any vertical stratification within the wells and then testing them to see if there was vertical flow.

- Matching sampling depth for each sampler with the pump intake for low-flow sampling.

- Carefully selecting a sampling order that reduces sampler impacts on subsequent sampling events.

\subsubsection{Baseline Characterization}

\subsubsection{Vertical Flow Testing}

Prior to sampling the wells for chemical analyses, the ambient vertical flow was determined in seven of the ten wells. This testing was conducted using an electromagnetic flowmeter. Details on how this device operates and the methods used in this study can be found in Parker et al. (in review). The ambient (non-pumping) flow test data indicated no detectable vertical flow in any of the seven wells tested at McClellan.

\subsubsection{Field Testing}

Ten 4-in.-diameter monitoring wells were selected for this field study. Nine of the wells had PVC casing with stainless steel screens; the tenth well was constructed with low-carbon steel casing and screen. Nine of the wells had $10-\mathrm{ft}$ length screens, and one well had a 15 -ft length screen. The depth to the water table historically ranged from 102 to $115 \mathrm{ft}$ bgs, and the top of screened interval ranged from 111 to $230 \mathrm{ft}$ bgs.

\subsubsection{Sampling Methods}

\subsubsection{Sampler Equipment}

For this demonstration, 1.6-in.-diameter bladder pumps already dedicated to the wells (and used for routine sampling) were used. The Snap Sampler equipment included: 40-mL Snap Sampler VOA vials, 125-mL and 350-mL HDPE Snap Sampler bottles, and acetal (Delrin) plastic Snap 
Sampler bodies. Because the water table was quite deep, an electronic trigger mechanism was used. The RGC samplers were constructed of the same materials and using the same methods for construction and handling as described previously for the Pease site.

\subsubsection{Sampler Deployment}

In each well, the (dedicated) bladder pump was removed from the well and was bundled with the Snap Samplers and one or two RGC samplers. The Snap Sampler trigger line contained four or five Snap Samplers in series; this included at least two VOA vials and two 125-mL plastic bottles. The samplers were placed so that they straddled (i.e., above and below) the entry port of the bladder pump, as shown in Figure 5-5. Additional QA/QC samples were also added as needed (discussed below). The equipment was then returned to the well and left to equilibrate for 3 weeks prior to collecting the samples.

\subsubsection{Sample Collection and Handling}

For each well, whole-water samples were collected using the Snap Sampler and low-flow sampling. These samples were analyzed for VOCs and total inorganics. Additional Snap Sampler and low-flow samples were collected and filtered in the field. These samples were analyzed for dissolved inorganic species. Having filtered and unfiltered samples allowed us to compare colloidal-borne and dissolved metal species. Because of the small pore-size of the RGC samplers, RGC samples could only be analyzed for VOCs and dissolved inorganics. Standard QA/QC samples were collected (as described for the Pease site), and the sampling order was the same as that used at the Pease site.

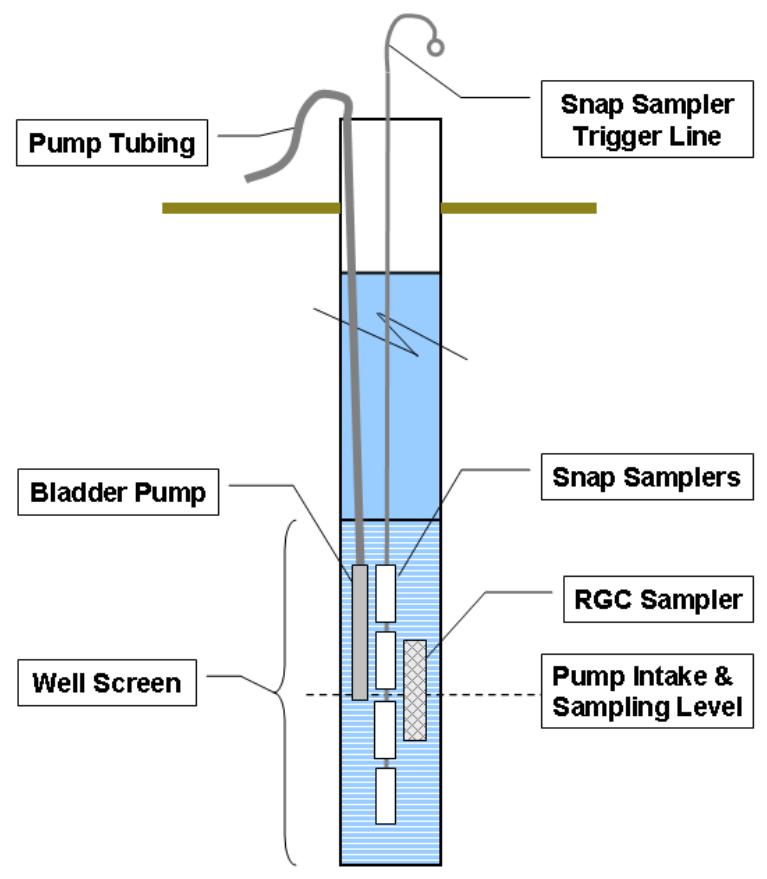

Figure 5-5. Deployment of the sampling equipment in the wells at the McClellan site. 


\subsubsection{Sample Analyses}

The VOCs were analyzed by EPA Method 8260B Gas Chromatography/Mass Spectrometry (GC/MS) (USEPA 1996). Metals were prepared for analyses using EPA Method 200.8 for Trace Elements in Water and Wastes by Inductively Coupled Plasma/Mass Spectrometry (ICP/MS) (USEPA 1994) and analyses were by EPA SW846 Method 6020A for inductively coupled plasma-mass spectrometry (USEPA 2007). The anions were analyzed using EPA Method 300.0, revision 2.1 (USEPA 1993). All samples were analyzed within the specified holding times.

\subsubsection{Statistical Analyses}

For the dissolved metals, analyte concentrations in the (filtered) Snap Sampler samples, (filtered) low-flow samples, and the RGC samplers were compared. For the total metals, and anions, analyte concentrations in the unfiltered Snap Sampler samples and the unfiltered low-flow samples were also compared. For the VOCs, analyte concentrations in the (unfiltered) Snap Sampler samples, (unfiltered) low-flow samples, and the RGC samplers were compared.

For the VOC and dissolved inorganic data, the statistical analyses used were the same as those used described for the Pease AFB data. For the total inorganic analytes (where only the Snap Sampler and low-flow sampling were compared), a paired $t$-test was used whenever a parametric test could be used, and when a non-parametric test was needed then a Wilcoxon Signed Rank Test was used.

\subsubsection{Sampling Results}

\subsubsection{Findings for the VOCs}

\subsection{Findings from the Analyses of the Field Duplicate Data}

Generally, agreement was quite good considering that many of the analyte concentrations were near the reporting limit. Our guideline for reproducibility was fairly stringent, with a Relative Percent Difference (RPD) of $25 \%$ or less, providing that concentrations of analytes were three times the reporting limit or greater. As an example, the RPD between 78 and $100 \mathrm{ppb}$ is $25 \%$.

For the low-flow samples, the RPD was less than $10 \%$ for all the analytes detected. For the Snap Sampler and RGC samples, there was more variability in the data. This is to be expected, given the individual nature of these samples vs. the low-flow samples that are poured into the VOA vials almost simultaneously. However, the Snap and RGC samplers provided reproducible results most of the time. For both samplers, the RPD was within our guideline for all but one of the comparisons (where analyte concentrations were less than the required three times the reporting limit).

\subsection{Comparison of the Three Sampling Methods}

The VOCs that were found at high enough concentrations to allow statistical analyses were carbon tetrachloride, CDCE, MTBE, and TCE. Statistical analyses of the data revealed that there were no statistically significant differences between the Snap Sampler and the low-flow sampling data for any of these analytes. Also, the linear model was a good fit for the comparisons between the low-flow and Snap Sampler data for carbon tetrachloride, CDCE, and TCE, but not 
MTBE. The linear model became a good fit for the MTBE data once one well (a possible outlier) was eliminated.

Statistical analyses comparing the RGC and low-flow data indicated that there also were no significant differences for the carbon tetrachloride and CDCE data. However, there were significant differences for the TCE and MTBE data. Although concentrations of TCE in the RGC samples were significantly lower than in the low-flow samples, there was no significant difference between the RGC and the Snap samples. MTBE concentrations were significantly higher in the RGC samples than in either the low-flow samples or the Snap samples. This analyte is highly soluble in water, more so than the other analytes, although it is not clear how this would have affected the results.

Although not included in the statistical analyses (because many of the data were either near or below the reporting limit), another trend we observed was that very low concentrations (i.e., just above the reporting limit) of acetone were detected in the RGC samplers but not in the Snap Sampler samples or the low-flow samples. This difference may be attributable to a difference in how these samplers were handled. Before we deployed these samplers, they were placed in a sparging chamber to deoxygenate the DI water inside. These chambers contained DI water that had been purchased locally and may have been the source of this contamination.

Although the RGC samplers have been used successfully in the past for sampling for MTBE (ITRC 2006), it is interesting that both MTBE and acetone concentrations were higher in the RGC samplers than in the other samplers. Both of these analytes are highly soluble in water. Vroblesky and Campbell (2001) found that the PDB sampler (with a PE membrane) should not be used for several highly soluble analytes, specifically acetone, MTBE, and Methyl Isobutyl Ketone.

\subsubsection{Dissolved Inorganic Analytes}

The dissolved inorganic analytes found at this site included one metalloid (As), two alkali metals ( $\mathrm{K}$ and $\mathrm{Na}$ ), three alkaline earth metals ( $\mathrm{Ba}, \mathrm{Ca}, \mathrm{Mg}$ ), and three transition metals $(\mathrm{Cr}, \mathrm{Ni}$, and $\mathrm{V}$ ).

\subsection{Findings from the Analyses of the Field Duplicate Data}

Generally, agreement was within our guideline (i.e., 25\% RPD or less) for most of the analytes for the three sampling methods. The exceptions were when the concentrations were near the detection limit. For $\mathrm{Ba}, \mathrm{Ca}, \mathrm{Cr}, \mathrm{Mg}, \mathrm{Ni}, \mathrm{K}, \mathrm{Na}$, and $\mathrm{V}$, the analyte concentrations were well above the reporting limit (at least three times the RL). For these analytes the agreement among replicate field samples was excellent, with the RPDs less than $10 \%$ for most of the samples.

The analytes where the concentrations were close to reporting limit were $\mathrm{As}, \mathrm{Cu}, \mathrm{Mn}$, and $\mathrm{Zn}$. For As and Mn, the RPDs were within the guidelines for all three sampling methods. For Zn, the RPDs for the field duplicate samples were within the guideline for low-flow sampling and the Snap Samplers but exceeded the guideline in two instances for the RGC samplers. For $\mathrm{Cu}$, the RPDs for low-flow sampling were within the guideline but exceeded the guideline in one instance for the Snap Sampler and in two instances for the RGC sampler. However, one would expect poorer precision for these analytes because the concentrations were either at or near the reporting limit. 


\subsection{Comparison of the Three Sampling Methods}

The analytes that were found at high enough concentrations to allow statistical analyses were As, $\mathrm{Ba}, \mathrm{Ca}, \mathrm{Cr}, \mathrm{Mg}, \mathrm{Ni}, \mathrm{K}, \mathrm{Na}$, and $\mathrm{V}$. Generally, there was exceptionally good agreement between the three sampling methods. There were no statistically significant differences between the lowflow and Snap Sampler samples for any of these analytes.

There also were no statistically significant differences between the RGC samples and the lowflow samples for As, $\mathrm{Ca}, \mathrm{Cr}, \mathrm{Ni}$, and $\mathrm{V}$. In contrast, concentrations of four analytes (Ba, Mg, K, and $\mathrm{Na}$ ) were significantly higher in the RGC samples than the low-flow samples, although these differences were generally very small, especially for $\mathrm{Ba}, \mathrm{Mg}$, and $\mathrm{Na}$. A linear-least-fit model of these data showed that the slope of the line for the Ba data was not significantly different from 1.0 , and the slope for the lines for the $\mathrm{Mg}$ and $\mathrm{Na}$ data were only slightly greater than 1.0 (i.e., 1.05 and 1.08, respectively). The difference between the two sampling methods was most pronounced for $\mathrm{K}$, where the slope was 1.15 . Concentrations of $\mathrm{K}$ were also significantly higher in the RGC samplers than in the Snap Sampler. These findings are somewhat perplexing given that $\mathrm{K}, \mathrm{Mg}$, and $\mathrm{Na}$ are the most soluble analytes.

\subsubsection{Total Inorganic Analytes}

Total concentrations of the inorganic analytes were only measured for low-flow sampling and the Snap Sampler. This was because the RGC membrane stops particles from entering. Total inorganic analytes that were found at measureable concentrations and that allowed statistical analyses included: two non-metal anions (chloride and sulfate), one metalloid (As), two alkali metals ( $\mathrm{K}$ and $\mathrm{Na}$ ), three alkaline earth metals ( $\mathrm{Ba}, \mathrm{Ca}, \mathrm{Mg}$ ), and several transition metals (Co, $\mathrm{Cr}$, $\mathrm{Cu}, \mathrm{Fe}, \mathrm{Mn}, \mathrm{Mo}, \mathrm{Ni}, \mathrm{V}$, and Zn).

\subsection{Findings from the Field Duplicate Data}

For analytes where the concentrations were well above the reporting limit, the data for the field duplicate samples for low-flow sampling and the Snap Sampler revealed that Ca, Mg, K, and Na, chloride, and sulfate had RPDs that consistently met our guideline.

The precision for $\mathrm{As}, \mathrm{Ba}, \mathrm{Ni}$, and sulfate was also generally within the guideline for both sampling methods. In contrast, the precision was very poor for $\mathrm{Cr}, \mathrm{Co}, \mathrm{Cu}, \mathrm{Fe}, \mathrm{Mn}$, and Mo for both sampling methods. In addition, the precision for the Snap Sampler data was poor for V. Because of the large variability in the data for several of these analytes, the results from the statistical analyses for these analytes should be taken with caution when no significant difference is found.

\subsection{Comparison of Low-Flow and Snap Sampler Data}

For both non-metal anions, chloride and sulfate, there was excellent agreement between the two sampling methods. The linear model was a good fit for both sets of data, and the statistical analyses revealed that there was no statistically significant difference between the two sampling methods.

It appears that concentrations of $\mathrm{As}, \mathrm{Ba}, \mathrm{Ca}, \mathrm{Mg}, \mathrm{K}, \mathrm{Na}$, and $\mathrm{V}$ agreed well between the two sampling methods and statistical analyses confirmed this. Analyses using a linear-least-fit model showed that more $98 \%$ of the variance observed could be explained by a linear model. 
Agreement was not as good for $\mathrm{Cr}, \mathrm{Co}, \mathrm{Cu}, \mathrm{Fe}, \mathrm{Mn}, \mathrm{Mo}, \mathrm{Ni}$, and $\mathrm{Zn}$. A linear-least-fit model of the data showed that the model was a poor fit for $\mathrm{Cr}, \mathrm{Cu}, \mathrm{Fe}$, and especially Zn. Statistical analyses of the data revealed that there were no statistically significant differences between the two sampling methods for $\mathrm{Cr}, \mathrm{Co}, \mathrm{Cu}, \mathrm{Mo}, \mathrm{Ni}$, and $\mathrm{Zn}$. This is not unexpected, given that analyte concentrations were near the reporting limit for $\mathrm{Co}, \mathrm{Cu}$, Mo, and $\mathrm{Zn}$, and that there was substantial variability between the replicate samples for these analytes and Cr. However, even though there also was very poor agreement between the duplicate samples for Fe and Mn, there were statistically significant differences between the two sampling methods for these analytes, with concentrations significantly higher in the Snap Sampler samples.

\subsection{Well-by-Well Comparisons}

In our field notes, we noted that the Snap samples from seven of the wells had particulates, either black or orange, or pieces of rusted casing or screen. The various types of debris in the samples can be seen in Figures 5-6, 5-7, and 5-8.

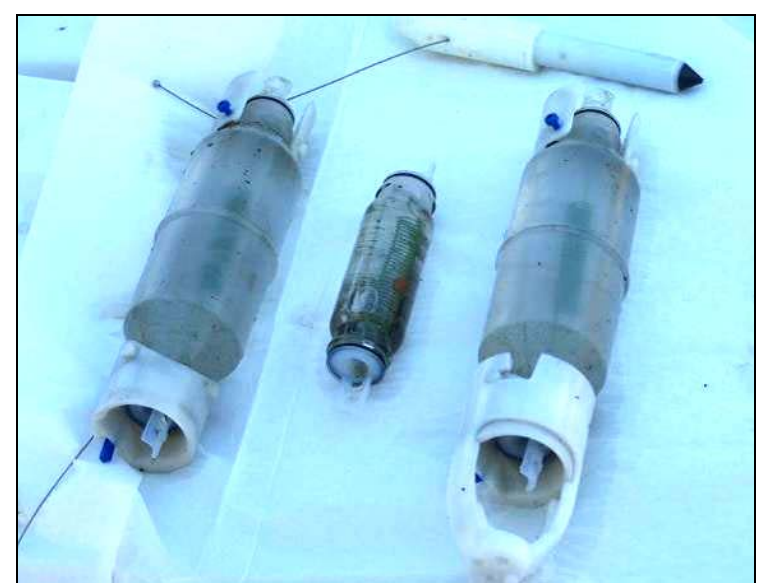

Figure 5-6. Snap Sampler samples showing black particles and piece of rusted casing (inside VOA vial).

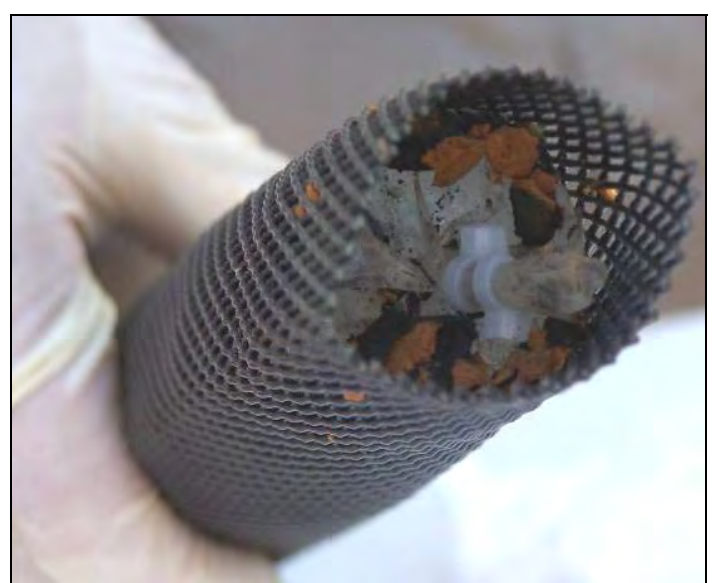

Figure 5-7. Top of RGC sampler showing deposits of large black and orange particles.

We believe that the orange precipitate was created when all the sampling equipment was placed in the well. This installation apparently agitated and oxygenated the well, and this formed hydrous iron oxides that then settled on the inside sloping wall of the Snap Sampler bottle and the spring (Fig. 5-7) and remained there until the Snap Sampler bottles were closed 3 weeks later.

We believe that the larger pieces of orange material were rusted well screen that had broken off. Concentrations of total iron were higher in the Snap Sampler samples than the low-flow samples for two of the wells where particles were found. In contrast, total iron concentrations were below the detection limit in two wells where particulate matter had not been observed.

The black particles may have been some type of biological film or could have been manganese oxides that were formed at the same time as the hydrous iron oxides. The presence of Mn oxides might explain the elevated levels of these analytes in some of these wells. Total Mn concentra- 
tions were higher in the Snap Sampler than in the low-flow samples in three wells. The presence of particulate Mn would explain the elevated concentrations of total Mn in these wells, where dissolved concentrations were at or near the reporting limit.

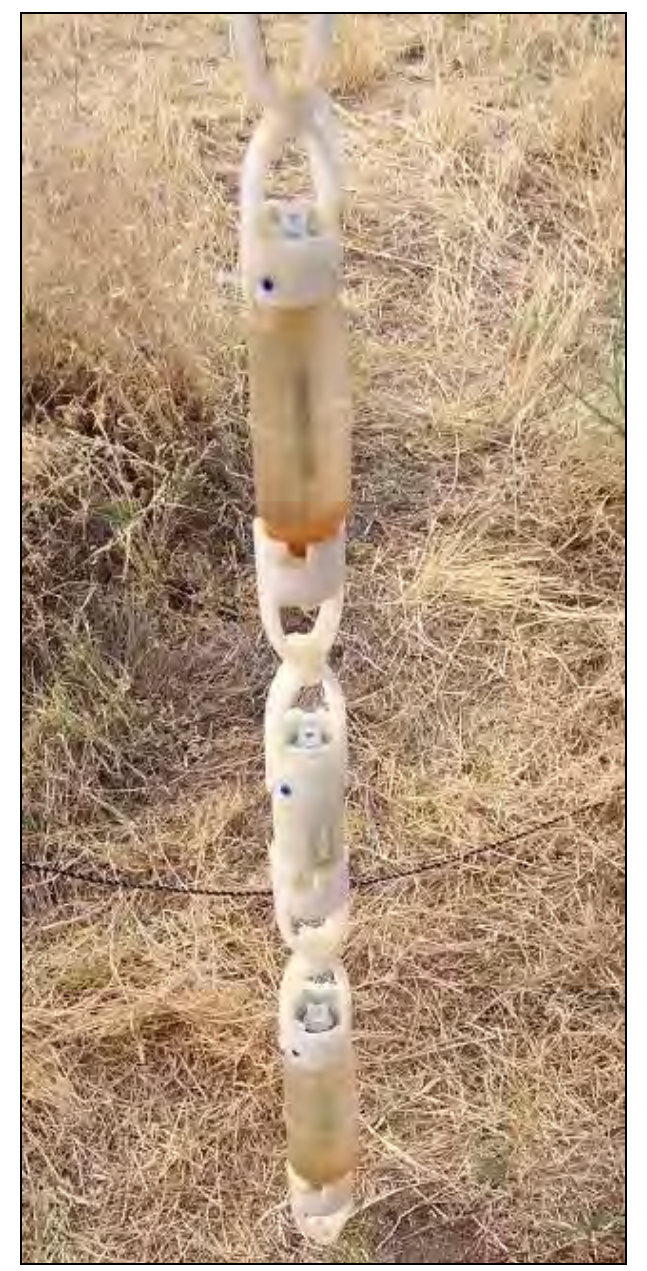

Figure 5-7. Snap Samplers containing an orange precipitate.

Concentrations of Co were also slightly higher in the same three wells. Elevated concentrations of this analyte may have resulted from coprecipitation with the hydrous iron or manganese oxides. In contrast, several of the other elements, including $\mathrm{Ba}, \mathrm{Ca}, \mathrm{Mg}, \mathrm{K}$, and $\mathrm{Na}$, are highly soluble and not subject to inclusion in hydrous oxide precipitates.

Nine of the wells used in this study were constructed with PVC casings and had slotted, stainless steel screens; the type of stainless steel was not specified. The other well had low-carbon steel casing and screen. The composition of low carbon steel is primarily iron but it also contains low concentrations of $\mathrm{Mn}(0.40$ to $1.5 \%)$. Constituents of type 304 stainless steel, the most commonly used steel in monitoring wells, include $\mathrm{Cr}$ (min. 18\%), Ni (min. 8\%), Mn (2\% max.), carbon (0.08\%), and Fe (remainder) (Driscoll 1986). Type 316 stainless steel, which is used in more corrosive environments, also contains Mo (min. 2\%) (Driscoll 1986). Several researchers (Hewitt 
1992; 1994; Oakley and Korte 1996) have shown that stainless steel 304 and 316 casings and screens leach $\mathrm{Ba}, \mathrm{Cd}, \mathrm{Cr}, \mathrm{Cu}, \mathrm{Fe}, \mathrm{Ni}$, and $\mathrm{Pb}$.

The low-carbon steel well had much higher concentrations of dissolved Fe and Mn than any of the other wells. Therefore, we believe that for some wells, the elevated concentrations of $\mathrm{Cr}, \mathrm{Cu}$, $\mathrm{Fe}, \mathrm{Mo}, \mathrm{Mn}$, and Ni reflects probable leaching of metal constituents from and corrosion of the stainless steel well screens.

The presence of pieces of rusted material in some of the Snap Sampler samples and on some of the RGC samplers, and the resilient high turbidity values during low-flow sampling (that did not respond to prolonged pumping) indicate that, in some wells, the well screens were corroded and that this led to an increase in the slot size (of the screens). An increased slot size would allow fines to enter these wells, thereby elevating the presence of particle-bound analytes.

\subsection{Conclusions for the Total Inorganic Analytes at this Site}

Given the poor reproducibility found for the field duplicate samples found with both the lowflow and Snap Sampler methods for total Cr, Co, Cu, Fe, Mn, and Mo, and the apparent leaching of constituents from the stainless steel screens (and low-carbon screen and casing), we would not recommend sampling from wells with steel screens for these analytes using either sampling method.

For those analytes where the precision of the replicates was within the recommended guidelines, there were no statistically significant differences between the two sampling methods. This includes As, Ba, Ca, Mg, K, Na, Zn, chloride, and sulfate.

For the other analytes ( $\mathrm{Cr}, \mathrm{Co}, \mathrm{Cu}, \mathrm{Fe}, \mathrm{Mn}$, and $\mathrm{Mo}$ ), where the reproducibility of the replicate field samples was poor, there were no statistically significant differences between the two sampling methods for $\mathrm{Cr}, \mathrm{Co}, \mathrm{Cu}$, and Mo. However, there was a statistically significant difference between low-flow sampling and the Snap Sampler for total Fe and Mn, with higher concentrations in the Snap Sampler. In addition, a well-by-well analysis of the data reveals that the Snap Sampler samples had substantially higher concentrations of constituent metals than low-flow sampling in some wells (i.e., well numbers 211, 225, and 333).

We believe that there may have been several causes for these differences and that the causes of the differences varied from well to well. These included: 1) leaching of metal constituents of the stainless steel (and low-carbon steel in one instance) screens; 2) corrosion of the well screen allowing fines to enter the well; and 3) installation of the sampling equipment in the well, which caused agitation of the wells and resulted in formation of hydrous iron and possibly manganese oxides. 


\subsection{PERFORMANCE ASSESSMENT}

\subsection{SNAP SAMPLER}

\subsubsection{Pease AFB Site}

Table 6-1 summarizes the findings for the performance objectives for the Snap Sampler. Generally, the Snap Sampler met the performance criteria and provided a very substantial cost savings over low-flow sampling.

\begin{tabular}{|c|c|c|c|}
\hline \multicolumn{4}{|c|}{ Table 6-1. Performance of the Snap Sampler at Pease AFB. } \\
\hline Performance objective & Data requirements & Success criteria & Results \\
\hline \multicolumn{4}{|c|}{ Quantitative } \\
\hline $\begin{array}{l}\text { 1. Equivalent analyte se- } \\
\text { lectivity }\end{array}$ & $\begin{array}{c}\text { Similar detection capa- } \\
\text { bilities to low-flow sam- } \\
\text { ples }\end{array}$ & $\begin{array}{l}\text { Sampler can recover } \\
\text { same analytes as low- } \\
\text { flow sampling }\end{array}$ & Yes \\
\hline $\begin{array}{l}\text { 2. Agreement between } \\
\text { analyte concentrations for } \\
\text { the two methods }\end{array}$ & $\begin{array}{l}\text { Analyte concentrations } \\
\text { for each sampling me- } \\
\text { thod for all wells }\end{array}$ & $\begin{array}{c}\text { Lack of statistically } \\
\text { significant differences }\end{array}$ & $\begin{array}{l}\text { Yes, except for total Fe, } \\
\text { esp. in the stainless } \\
\text { steel and turbid wells }\end{array}$ \\
\hline 3. Reduced sampling time & $\begin{array}{l}\text { Field records of activities } \\
\text { at each well }\end{array}$ & $\begin{array}{l}\text { Less time needed to } \\
\text { sample a well }\end{array}$ & Yes \\
\hline 4. Reduced purge water & $\begin{array}{l}\text { Document volume and } \\
\text { disposal time }\end{array}$ & Reduced waste water & Yes \\
\hline $\begin{array}{l}\text { 5. Less costly sampling } \\
\text { method }\end{array}$ & $\begin{array}{l}\text { - Records of the costs for } \\
\text { equipment and supplies } \\
\text { - Field record of field } \\
\text { crew's time }\end{array}$ & $\begin{array}{l}\text { Cost savings of at } \\
\text { least } 25 \%\end{array}$ & Yes, 67\% cost savings \\
\hline \multicolumn{4}{|c|}{ Qualitative } \\
\hline $\begin{array}{l}\text { 1. Mechanical perfor- } \\
\text { mance }\end{array}$ & $\begin{array}{c}\text { Field records of activities } \\
\text { at each well }\end{array}$ & $\begin{array}{l}\text { Samplers work as de- } \\
\text { scribed without prob- } \\
\text { lems, reliable, etc }\end{array}$ & Generally, yes \\
\hline 2.Ease of use & $\begin{array}{c}\text { Field records of activities } \\
\text { at each well }\end{array}$ & Easy to use & Yes \\
\hline 3. Safety & $\begin{array}{c}\text { Field records of activities } \\
\text { at each well }\end{array}$ & $\begin{array}{l}\text { Generally as safe or } \\
\text { safer to collect sam- } \\
\text { ples as with low-flow } \\
\text { sampling }\end{array}$ & Yes \\
\hline 4. Training & $\begin{array}{c}\text { Field records and user } \\
\text { input }\end{array}$ & $\begin{array}{l}\text { Relatively little train- } \\
\text { ing required }\end{array}$ & Yes \\
\hline
\end{tabular}

\subsubsection{Equivalent Analyte Selectivity}

In all cases, we were able to collect the sample volume needed for these analyses. Because the sample volumes were the same for the Snap Sampler and low-flow sampling, the detection capability was the same for the two sampling methods. 


\subsubsection{Agreement between Analyte Concentrations for the Two Sampling Methods}

Based upon the statistical analyses, analyte concentrations in samples collected with the Snap Sampler were found to be equivalent to those in the low-flow samples with one exception, unfiltered iron where concentrations were significantly higher in the Snap Sampler samples. Differences were most pronounced in samples collected from the two stainless steel wells and wells with higher turbidity levels. Elevated turbidities may have resulted from installing additional sampling equipment (including the baffle, pump, samplers, and bottom weight) in the well before sampling, poor well construction, or corrosion (degradation) of the stainless steel screens, or all three.

\subsubsection{Reduced Sampling Time}

The sampling time for the Snap Sampler was considerably less than that needed for low-flow sampling as only one person is needed to collect a sample. While one individual can also conduct low-flow sampling, generally a field crew of two appears to be the industry norm and is preferred.

We also determined that during normal sampling events, the Snap sampling time would be less than that for the RGC sampler. Only one trip to the field would be needed for the Snap Sampler, whereas the RGC sampler would require two trips to the field-one to deploy the sampler and one to recover the sampler. In contrast, new Snap Sampler bottles can be deployed in the well at the end of a sampling event and left in place until the next sampling event.

\subsubsection{Reduced Purge-Water Volume}

Because the Snap Sampler samples were shipped to the laboratory in the same bottles in which the samples were collected, there was no purge water or other waste water that required disposal.

\subsubsection{Reduced Sampling Cost}

We selected a minimum cost savings of $25 \%$ as our guideline for this sampler (compared with low-flow sampling). However, the estimated cost savings were considerably greater than our initial goal, with a 67\% cost savings (based upon a similar site with 50 wells and quarterly sampling). This will be discussed in more detail in section 7.

\subsubsection{Mechanical Performance of Snap Sampler}

Generally, the Snap Samplers performed well by triggering on demand and providing full samples. Out of the 41 samples collected, there were four instances when one of the caps did not seal properly because the o-ring did not seat properly. In instances where the o-ring was on the bottom of the sampler, there was leakage of some of the sample as it was withdrawn from the well. In two cases, there was excessive sediment in the samples; it is likely that these particles prevented the o-rings from seating properly. Later, the laboratory discovered that two bottles had pinhole leaks in the seam and there was some loss of sample during shipping and storage. These bottles were returned to the developer. The developer has since changed the polymer that the bottles are made out of from PP to HDPE, which they claim has better weld properties. There also was one instance where we found that the top cap of one of the samplers deployed prematurely, and there was one instance during deployment where the ball connector had pulled off the trigger line. In these instances the samplers had to be redeployed. Because there were issues with some of the samples collected, we would recommend deploying an additional bottle as insurance. 


\subsubsection{Ease of Use}

We found that this sampler required training and some repetition for smooth operation.

\subsubsection{Safety}

Although there were no injuries related to using any of the three sampling technologies, there are fewer safety concerns associated with the Snap Sampler (compared with low-flow sampling). Possible safety issues with the Snap Sampler include injury from piercing the septum (to add acid to the sample bottle), spilling acid while adding acid to the sample bottle, and brief exposure to the sample's contaminants if the sample is transferred to another container. In contrast, there are numerous safety concerns associated with low-flow sampling. These include electrical concerns with using the pump, generator, and ancillary electronic equipment (especially in the rain); spillage and fire hazards associated with working with gasoline and running a generator; possible burns from generator's muffler; strained or pulled muscles from moving heavy equipment in and out of the vehicle; prolonged exposure to the sample's contaminants during purging, sampling, and waste disposal; spilling acid from the sample bottles; and tripping over electrical cords.

\subsubsection{Training}

With respect to the training time needed to become proficient with the sampling method, the Snap Sampler required a longer training time than did the RGC sampler. We found that it took several minutes of training and some practice to become proficient in using this sampler.

\subsubsection{McClellan site}

Table 6-2 summarizes the performance findings. Generally, the Snap Sampler met the performance criteria.

\subsubsection{Ability to Sample a Range of Contaminants at the Site}

This is the first site where we have used the Snap Sampler to collect samples for a number of analyte types (including VOCs, dissolved metals, total metals, total anions, and dissolved and total Fe[2] for field analyses). This required that we collect a minimum of $300 \mathrm{~mL}$ of sample (not including the QA/QC samples), thereby increasing the needed sample volume and number of sample bottles. In all cases, we were able to collect the sample volume needed for these analyses, and thus the detection capability was the same for the two sampling methods.

\subsubsection{Reproducible Data}

The guideline for this objective was that the \%RSD between the field replicate samples either be $25 \%$ or less, or be equivalent to (or better than) that for the low-flow samples. These requirements were only for analytes where the concentrations were equal to (or greater than) three times the reporting limit. 
Table 6-2. Performance of the Snap Sampler at the McClellan site.

\begin{tabular}{|c|c|c|c|}
\hline Performance objective & Data requirements & Success criteria & Results \\
\hline \multicolumn{4}{|c|}{ Quantitative } \\
\hline $\begin{array}{l}\text { 1. Ability to sample a } \\
\text { range of contaminants at } \\
\text { site }\end{array}$ & $\begin{array}{l}\text { Adequate sample volume } \\
\text { for all analyses }\end{array}$ & $\begin{array}{l}\text { Similar detection ca- } \\
\text { pabilities (as with low- } \\
\text { flow sampling) }\end{array}$ & Yes \\
\hline 2. Reproducible data & $\begin{array}{c}\text { Analyte data for replicate } \\
\text { samples }\end{array}$ & $\begin{array}{l}\text { Among replicate sam- } \\
\text { ples, a \%RSD of } 25 \% \\
\text { or less, or equal to or } \\
\text { better than that for } \\
\text { low-flow samples }\end{array}$ & $\begin{array}{l}\text { Yes for VOCs, dissolved } \\
\text { inorganics, and total non- } \\
\text { metal ions. } \\
\text { Issues with some total metals } \\
\text { for Snap Sampler and low- } \\
\text { flow sampling }\end{array}$ \\
\hline $\begin{array}{l}\text { 3. Agreement between } \\
\text { sampling methods for } \\
\text { analytes of interest }\end{array}$ & $\begin{array}{l}\text { Analyte concentrations for } \\
\text { each sampling method for } \\
\text { all wells }\end{array}$ & $\begin{array}{c}\cdot \text { - Lack of statistically } \\
\text { significant differences } \\
\text { • Lack of bias } \\
\end{array}$ & $\begin{array}{l}\text { Yes, with two exceptions: } \\
\text { total Fe and total Mn }\end{array}$ \\
\hline 4. Reduced sampling time & $\begin{array}{l}\text { Field records of activities } \\
\text { at each well }\end{array}$ & $\begin{array}{l}\text { Less time needed to } \\
\text { sample a well }\end{array}$ & Yes \\
\hline $\begin{array}{l}\text { 5. Less costly sampling } \\
\text { method }\end{array}$ & $\begin{array}{l}\text { - Records of the costs for } \\
\text { equipment and supplies } \\
\text { - Field record of techni- } \\
\text { cian's time }\end{array}$ & $\begin{array}{c}\text { Cost savings of at least } \\
25 \%\end{array}$ & Yes, $46 \%$ cost savings \\
\hline \multicolumn{4}{|c|}{ Qualitative } \\
\hline 1. Ease of use & $\begin{array}{c}\text { Field records of activities } \\
\text { at each well }\end{array}$ & $\begin{array}{l}\text { Technician able to } \\
\text { learn the procedure } \\
\text { with relative ease. }\end{array}$ & Yes \\
\hline 2.Ease of use & $\begin{array}{c}\text { Field records of activities } \\
\text { at each well }\end{array}$ & $\begin{array}{l}\text { Few problems requir- } \\
\text { ing second attempt to } \\
\text { sample the well }\end{array}$ & $\begin{array}{l}\text { Yes (providing manufactur- } \\
\text { er's directions were fol- } \\
\text { lowed) }\end{array}$ \\
\hline 3. Ease of Use & $\begin{array}{l}\text { Feedback from field tech- } \\
\text { nician }\end{array}$ & Operator acceptance & Yes \\
\hline
\end{tabular}

With only a few exceptions, the replicate data was within the guidelines for the Snap Sampler for the VOCs, dissolved inorganics, and total non-metal ions. However, this was not the case for the total metals. The RPD exceeded the guideline for both the Snap Sampler and low-flow sampling for $\mathrm{Cr}, \mathrm{Fe}$, and $\mathrm{Mn}$. This was also true for both sampling methods for $\mathrm{Co}, \mathrm{Cu}$, and $\mathrm{Mo}$, although, concentrations of these analytes were at or near the reporting limit. The RPD also exceeded the guideline for $\mathrm{V}$ with the Snap Sampler samples. Given the poor reproducibility found for the field duplicate samples with both sampling methods and the apparent leaching of constituents of the stainless steel screens, we would not recommend using wells with steel casings or screens for sampling for these analytes using either sampling method.

\subsubsection{Agreement Between Analyte Concentrations for the Two Sampling Methods}

Statistical analyses of the data revealed that generally there was excellent agreement between analyte concentrations in the Snap Sampler and low-flow sampling, and that these relationships were linear with the slopes equal to 1.0. There were no statistically significant differences between the two sampling methods for the VOCs, dissolved inorganics, total non-metal anions, and 
most of the total metals and metalloids. The exceptions to this were for total Fe and total $\mathrm{Mn}$, where concentrations of Fe and Mn were significantly higher in the Snap Sampler samples.

We believe that there may have been several causes for the elevated concentrations of total Fe and Mn. These causes include: 1) leaching of metal constituents of the stainless steel screens and low-carbon steel casing and screen; 2) corrosion of the well screens allowing fines to enter the well; and 3) placing all the sampling equipment in the well, which agitated the well and elevated the level of fines in the well or caused the formation of hydrous iron and possibly manganese oxides.

\subsubsection{Reduced Sampling Time}

Field records revealed that the time needed to sample with the Snap Sampler was less than one fourth that needed for low-flow purging and sampling.

\subsubsection{Less Costly Sampling Method}

The cost savings for this site were determined to be approximately $46 \%$. This is less than the $67 \%$ cost savings found for the Pease site but exceeds our guideline of $25 \%$. The Snap Sampler was more expensive to use at the McClellan site because more samples were collected and the wells were considerably deeper than at the Pease site. The detailed cost analyses can be found in section 7.0.

\subsubsection{Ease of Use}

All three qualitative measures of this performance objective were met. The developer had previously redesigned the sampler to make assembly of multiple samplers on the same trigger line more fool-proof. Specifically, the up direction on the samplers was clearly marked and the connecting pieces were fabricated so that it was impossible to assemble a string of samplers incorrectly (i.e., upside down). As a result, all of the field crew were able to assemble the samplers with relative ease and our new field technician learned the procedure quickly. The only instances where the samplers had to be redeployed were when the manufacturer's directions for cocking the samplers prior to deployment were not properly followed. With a more recent redesign of the samplers, this also can no longer happen (i.e., the manufacturer added a stop so that the pin cannot be cocked too far open).

\subsection{PERFOMRMANCE ASSESSMENT OF THE RGC SAMPLER}

\subsubsection{Pease Site}

Table 6-3 summarizes the findings for the performance objectives for the RGC samplers at the Pease Site. This sampler generally met the performance criteria, with the exception that it could not be used to collect samples for total metals.

\subsubsection{Equivalent Analyte Selectivity}

Unlike the low-flow and Snap Sampler samples, the RGC samples cannot be used to determine total concentrations of the inorganic analytes. This is because the small pore size of the membrane prevents particles from entering the samplers. 
Table 6-3. Performance of the RGC Sampler at Pease AFB.

\begin{tabular}{|c|c|c|c|}
\hline Performance objective & Data requirements & Success criteria & Results \\
\hline \multicolumn{4}{|c|}{ Quantitative } \\
\hline $\begin{array}{l}\text { 1. Equivalent analyte } \\
\text { selectivity }\end{array}$ & $\begin{array}{c}\text { Similar detection capa- } \\
\text { bilities to low-flow sam- } \\
\text { ples }\end{array}$ & $\begin{array}{c}\text { Sampler can recover } \\
\text { same analytes as low- } \\
\text { flow sampling }\end{array}$ & $\begin{array}{l}\text { Sampler cannot recover } \\
\text { total concentrations of } \\
\text { inorganic analytes }\end{array}$ \\
\hline $\begin{array}{l}\text { 2. Agreement between } \\
\text { analyte concentrations } \\
\text { for the two methods }\end{array}$ & $\begin{array}{l}\text { Analyte concentrations } \\
\text { for each sampling me- } \\
\text { thod for all wells }\end{array}$ & $\begin{array}{l}\text { Lack of statistically sig- } \\
\text { nificant differences }\end{array}$ & $\begin{array}{c}\text { Generally yes, exceptions } \\
\text { were due to differences in } \\
\text { when the low-flow sam- } \\
\text { ples were filtered }\end{array}$ \\
\hline $\begin{array}{l}\text { 3. Reduced sampling } \\
\text { time }\end{array}$ & $\begin{array}{l}\text { Field records of activi- } \\
\text { ties at each well }\end{array}$ & $\begin{array}{l}\text { Less time needed to } \\
\text { sample a well }\end{array}$ & Yes \\
\hline 4. Reduced purge water & $\begin{array}{c}\text { Document volume and } \\
\text { disposal time }\end{array}$ & Reduced waste water & Yes \\
\hline $\begin{array}{l}\text { 5. Less costly sampling } \\
\text { method }\end{array}$ & $\begin{array}{l}\text { - Records of the costs for } \\
\text { equipment and supplies } \\
\text { - Field record of techni- } \\
\text { cian's time }\end{array}$ & $\begin{array}{c}\text { Cost savings of at least } \\
25 \%\end{array}$ & Yes, $71 \%$ cost savings \\
\hline \multicolumn{4}{|c|}{ Qualitative } \\
\hline $\begin{array}{l}\text { 1. Mechanical Perfor- } \\
\text { mance }\end{array}$ & $\begin{array}{l}\text { Field records of activi- } \\
\text { ties at each well }\end{array}$ & $\begin{array}{l}\text { Samplers work as de- } \\
\text { scribed without prob- } \\
\text { lems, reliable, etc }\end{array}$ & Yes \\
\hline 2.Ease of use & $\begin{array}{l}\text { Field records of activi- } \\
\text { ties at each well }\end{array}$ & Easy to use & $\begin{array}{l}\text { Yes, easiest of the three } \\
\text { methods tested }\end{array}$ \\
\hline 3. Safety & $\begin{array}{l}\text { Field records of activi- } \\
\text { ties at each well }\end{array}$ & $\begin{array}{c}\text { Generally as safe or } \\
\text { safer to collect samples } \\
\text { as with low-flow sam- } \\
\text { pling }\end{array}$ & Yes \\
\hline 4. Training & $\begin{array}{l}\text { Field records and user } \\
\text { input }\end{array}$ & $\begin{array}{c}\text { Relatively little training } \\
\text { required }\end{array}$ & Yes \\
\hline
\end{tabular}

\subsubsection{Agreement Between Analyte Concentrations for the Two Sampling Methods}

There was no statistically significant difference between the concentrations of dissolved $\mathrm{Ca}, \mathrm{Mg}$, $\mathrm{Mn}$ and $\mathrm{K}$ in the RGC samples compared with the filtered low-flow samples. However, there were statistically significant differences for As, Fe, and Na. Dissolved concentrations of As and Fe were significantly higher and concentrations of Na were lower in the RGC samples. Because the low-flow (and Snap Sampler) samples were filtered in the laboratory, it is reasonable to assume that there were losses of iron from the precipitation of hydrous iron oxides that occurred during shipping and storage (prior to filtration), and that the losses of the As anion resulted from co-precipitation with the hydrous iron oxides. Therefore, we suspect that the concentrations of Fe and As in the RGC samples were actually more representative of the in-situ concentrations in the well screen. In contrast, the lower concentrations of $\mathrm{Na}$ in the RGC samples may be because low-flow pumping brought in more saline water from the surrounding estuary; this difference was most pronounced in the two shallowest wells. 


\subsubsection{Reduced Sampling Time}

The sampling time for the RGC sampler was considerably less than that needed for low-flow sampling. This is because only one person is needed to collect the samples and the samples can be collected immediately, vs. waiting for the purge parameters to stabilize with low-flow sampling. However, sampling with the RGC samplers required more time than that needed to collect a sample with the Snap Sampler. This is because only one trip to the field is needed for the Snap Sampler whereas, the RGC sampler requires two trips to the field (one to deploy the sampler and one to recover it).

\subsubsection{Reduced Purge Water}

For the RGC sampler, there also was no purge water that required disposal but, there were small amounts of residual sample water that required disposal.

\subsubsection{Less Costly Sampling Methods}

The total estimated cost for sampling 50 wells quarterly for 10 years using low-flow sampling was approximately $\$ 907.6 \mathrm{~K}$ (Table 7-1). This assessment is based upon a two-person field crew for low-flow sampling and field crew of one for the RGC sampler. The estimated cost for using the RGC sampler at this site was $\$ 257.9 \mathrm{~K}$ (Table 7-3), which is a cost savings of $71 \%$.

\subsubsection{Mechanical Performance}

There are no moving parts on the RGC samplers so the only problems that might occur would be tearing, causing loss of the sampler or degradation of the membrane. However, no problems were encountered during this demonstration.

\subsubsection{Ease of Use}

This sampler was the easiest of the three sampling methods tested.

\subsubsection{8 $\underline{\text { Safety }}$}

As mentioned previously, there were no injuries related to using any of the three sampling technologies. However, there were far fewer safety concerns with the two passive samplers. For the RGC sampler, possible issues include spilling acid from the sample bottle, and exposure to the sample's contaminants during transfer or during disposal. In contrast, there are numerous safety concerns associated with low-flow sampling (listed previously in section 6.1.1).

\subsubsection{Training}

Training to deploy the RGC samplers is relatively minimal. The guidance on their construction was also easy to follow. The only issue that we encountered was that there was no guidance about what width of dialysis tubing or diameter of support tubing to order. Also, the manufacturer only lists the flat width of the tubing. Therefore, it is important to correctly calculate the diameter of dialysis tubing when filled so that the support tubing fits inside the dialysis membrane. 


\subsubsection{Performance Assessment of the RGC Sampler at the McClellan Site}

Table 6-4 summarizes the findings for the performance objectives for the RGC sampler at the McClellan site. Generally, this sampler met the performance criteria and was easy to use. However, the applicability of this sampler is more limited than the Snap Sampler because it can only be used for dissolved constituents.

\begin{tabular}{|c|c|c|c|}
\hline Performance objective & Data requirements & Success criteria & Results \\
\hline \multicolumn{4}{|c|}{$\begin{array}{l}\text { Quantitative } \\
\end{array}$} \\
\hline $\begin{array}{l}\text { 1. Ability to sample a } \\
\text { range of contaminants at } \\
\text { site }\end{array}$ & $\begin{array}{l}\text { Adequate sample volume } \\
\text { for all analyses }\end{array}$ & $\begin{array}{l}\text { Similar detection capa- } \\
\text { bilities (as with low- } \\
\text { flow sampling) }\end{array}$ & $\begin{array}{l}\text { Yes, but cannot be used } \\
\text { to sample for total inor- } \\
\text { ganic analytes }\end{array}$ \\
\hline 2. Reproducible data & $\begin{array}{l}\text { Analyte data for repli- } \\
\text { cate samples }\end{array}$ & $\begin{array}{l}\text { Among replicate sam- } \\
\text { ples, a \%RSD of } 25 \% \\
\text { or less, or equal to or } \\
\text { better than that for low- } \\
\text { flow samples }\end{array}$ & $\begin{array}{l}\text { Yes, with one exception } \\
\text { (one analyte in one well) }\end{array}$ \\
\hline $\begin{array}{l}\text { 3. Agreement between } \\
\text { sampling methods for ana- } \\
\text { lytes of interest }\end{array}$ & $\begin{array}{l}\text { Analyte concentrations } \\
\text { for each sampling me- } \\
\text { thod for all wells }\end{array}$ & $\begin{array}{c}\cdot \text { Lack of statistically } \\
\text { significant differences } \\
\text { • Lack of bias }\end{array}$ & $\begin{array}{c}\text { Yes for some VOCs and } \\
\text { dissolved inorganics but } \\
\text { not all }^{1}\end{array}$ \\
\hline 4. Reduced sampling time & $\begin{array}{l}\text { Field records of activi- } \\
\text { ties at each well }\end{array}$ & $\begin{array}{l}\text { Less time needed to } \\
\text { sample a well }\end{array}$ & Yes \\
\hline $\begin{array}{l}\text { 5. Less costly sampling } \\
\text { method }\end{array}$ & $\begin{array}{c}\text { - Records of the costs } \\
\text { for equipment and sup- } \\
\text { plies } \\
\text { - Field record of techni- } \\
\text { cian's time }\end{array}$ & $\begin{array}{c}\text { Cost savings of at least } \\
25 \%\end{array}$ & Yes, 67\% \\
\hline \multicolumn{4}{|c|}{$\begin{array}{c}\text { Qualitative } \\
\end{array}$} \\
\hline 1. Ease of use & $\begin{array}{l}\text { Field records of activi- } \\
\text { ties at each well }\end{array}$ & $\begin{array}{c}\text { - Technician able to } \\
\text { learn the procedure } \\
\text { with relative ease. } \\
\text { - Few problems requir- } \\
\text { ing second attempt to } \\
\text { sample the well } \\
\text { - Operator acceptance }\end{array}$ & $\begin{array}{l}\cdot \text {-Yes very easy to use } \\
\cdot \text { Yes } \\
\text { • Yes }\end{array}$ \\
\hline $\begin{array}{l}\text { here were no statistically si } \\
\text { nples for carbon tetrachlori } \\
\text { en the two sampling metho } \\
\text { C samplers. }\end{array}$ & $\begin{array}{l}\text { ificant differences betwee } \\
\text {, cDCE, As, } \mathrm{Ca}, \mathrm{Cr}, \mathrm{Ni} \text {, an } \\
\text { for TCE, Ba, Mg, K, and }\end{array}$ & $\begin{array}{l}\text { the concentrations in the } \\
\text { V. Statistically significa } \\
\text { Na. Also, MTBE and acet }\end{array}$ & $\begin{array}{l}\text { GC samplers and low-flow } \\
\text { differences were found be } \\
\text { le were only detected in the }\end{array}$ \\
\hline
\end{tabular}




\subsubsection{Ability to Sample a Range of Contaminants at the Site}

As mentioned previously, because of the small pore size of the RGC membrane, RGC sampler samples could not be analyzed for either total anions or total metals. Because most risk assessors are interested in the total contaminant load, this could prevent the use of this sampler for risk analyses. The RGC sampler provided adequate sample volume for the analyses of those analytes that could be measured, and thus the sensitivity of those analyses was comparable with low-flow sampling.

\subsubsection{Reproducibility of the RGC Sampler}

When the analyte concentrations were not near the reporting limit, the replicate field data for the RGC samplers were within the guideline $(\leq 25 \%$ RPD) for the VOCs and for the dissolved inorganic analytes with one exception: in one or four wells where the RPD for K was only slightly above the guideline.

\subsubsection{Agreement Between Analyte Concentrations of the Two Sampling Methods}

As mentioned previously, only concentrations of VOCs and dissolved inorganics could be compared for the RGC sampler. For the VOCs, the RGC sampler recovered equivalent concentrations of carbon tetrachloride and cDCE. In contrast, concentrations of MTBE and acetone were detected in the RGC samples but not the low-flow or Snap Sampler samples or the RGC equipment blanks. We were not able to determine why this was the case for MTBE but suspect that acetone may have been a contaminant in the bottled distilled water that was purchased on-site (and used only with this sampler). In contrast, concentrations of TCE were significantly lower in the RGC samplers than those collected using low-flow sampling (but not the Snap Sampler).

There was good agreement between the concentrations of dissolved As, Ca, Cr, Ni, and V. Concentrations were slightly significantly higher for $\mathrm{Ba}, \mathrm{Mg}, \mathrm{K}$, and $\mathrm{Na}$ in the RGC sampler. This was discussed in more detail in section 5.2.6.

\subsubsection{Reduced Sampling Time}

Even though this sampling method requires two trips to the field and time to assemble the sampler, this performance standard was easily met. We calculated that the total labor time for sampling this site (with 50 wells) with the RGC sampler would be $31 \%$ of the time needed to sample using low-flow sampling.

\subsubsection{Less Costly Sampling Method}

The projected cost savings for this sampler at this site was $67 \%$ vs. the low-flow sampling cost (for a similar site with 50 wells that are sampled quarterly over ten years).

\subsubsection{Ease of Use}

We found that this sampler was very easy to use and was well liked by the field crew. The only issue was in one well where the sampler fell of the line. That sampler was eventually recovered but it was badly torn by the hook used to recover it. 


\subsection{COST ASSESSMENT}

\subsection{COST MODEL}

Cost models for long-term monitoring of a site with 50 monitoring wells and quarterly sampling over 10 years were developed for low-flow purging and sampling, the Snap Sampler, and the RGC sampler sites at each of the sites. Generic forms of those models can be found in Tables 7-1, 7-2, and 7-3, respectively. For each sampling method, the cost model consists of two cost elements: the initial startup costs and the quarterly sampling costs. Both cost elements consist primarily of two elements: labor and materials (equipment and supplies). Labor for each sampling method was determined by recording in the field notebook the time needed for each task conducted in the field. Material costs were determined by current purchase prices or rental costs.

\subsubsection{Initial Startup Costs}

Labor costs for the initial startup consist of the time needed to plan field work and order necessary equipment, and the time needed to install the equipment in the wells. For the RGC samplers, it would also include the time needed to construct the samplers. At the Pease site, we also included the cost of reconditioning the wells because they clearly needed to be redeveloped. This was included in the cost of the passive samplers but not low-flow sampling. Although this decision was based upon common practice throughout the industry, one could argue that reconditioning the wells should have also been included in the cost of low-flow sampling.

Table 7-1. Cost model for low-flow sampling.

\begin{tabular}{|c|c|c|c|}
\hline Cost element & Data tracked during the demonstration & \multicolumn{2}{|l|}{ Costs } \\
\hline \multirow[t]{9}{*}{ Initial startup } & $\begin{array}{l}\text { - Labor: initial planning fieldwork, pur- } \\
\text { chasing equipment and supplies, }\end{array}$ & Project technician & $\$ 60 / \mathrm{hr}$ \\
\hline & \multirow[t]{7}{*}{$\begin{array}{l}\text { Equipment and supplies: One-time } \\
\text { purchases (50 wells) }\end{array}$} & $\begin{array}{l}\text { Bladder pump, 3/4-in. } \\
\text { stainless }\end{array}$ & $\$ 500 /$ pump \\
\hline & & Tubing (10-m roll) & \$202/role \\
\hline & & Generator (1) & $\$ 1100 /$ ea. \\
\hline & & Air Compressor (1) & \$180/ea. \\
\hline & & Pump Controller (1) & $\$ 1760 /$ ea. \\
\hline & & $\begin{array}{l}\text { Water Quality Meter, } \\
\text { flow cell ( } 1 \text { each) }\end{array}$ & $\$ 5850$ \\
\hline & & Nylon-coated wire line & $\$ 1.00 / \mathrm{ft}$. \\
\hline & - $\quad$ Labor: Installation of equipment & Project technician (2) & $\$ 120 / \mathrm{hr}$ \\
\hline \multirow{2}{*}{$\begin{array}{l}\text { Quarterly sam- } \\
\text { pling costs }\end{array}$} & • $\quad$ Supplies & Materials & $\$ 285$ \\
\hline & $\begin{array}{l}\text { Labor: sampling } 50 \text { wells and waste } \\
\text { disposal }\end{array}$ & Project technicians (2) & $\$ 120 / \mathrm{hr}$ \\
\hline \multirow{5}{*}{$\begin{array}{l}\text { Long-term moni- } \\
\text { toring costs }\end{array}$} & \multirow[t]{3}{*}{ • $\quad$ Total Costs, no inflation } & Annual sampling cost & Sum \\
\hline & & Total costs after 1 year & \\
\hline & & After 10 years & \\
\hline & \multirow{2}{*}{$\begin{array}{l}\text { - } \quad \text { Cumulative Costs, assuming OMB's } \\
2.2 \% \text { annual inflation }\end{array}$} & After 1 year & \\
\hline & & After 10 years & \\
\hline
\end{tabular}


Table 7-2. Cost model for sampling using Snap Samplers based upon McClellan site.

\begin{tabular}{|c|c|c|c|}
\hline Cost element & $\begin{array}{c}\text { Data tracked during the demonstra- } \\
\text { tion }\end{array}$ & \multicolumn{2}{|l|}{ Costs } \\
\hline \multirow[t]{10}{*}{ Initial startup } & $\begin{array}{l}\text { Labor: initial planning fieldwork, } \\
\text { purchasing equipment and supplies }\end{array}$ & Project technician (1) & $\$ 60 / \mathrm{hr}$ \\
\hline & \multirow{7}{*}{$\begin{array}{l}\text { - } \quad \text { Materials: One-time purchases of } \\
\text { Snap Sampler equipment (50 wells) }\end{array}$} & Snap bottle (any size) & \$16/ea. \\
\hline & & Snap holder (any size) & \$165/ea. \\
\hline & & Trigger line, fabrication fee & \$85/line \\
\hline & & (1) Electronic trigger switch ${ }^{1}$ & \$175/ea. \\
\hline & & $\begin{array}{l}\text { Down-hole actuator } \\
\text { (one/well) }^{1}\end{array}$ & $\$ 32.50 /$ ea \\
\hline & & 28-v. batteries, charger case ${ }^{1}$ & $\$ 560 /$ ea. \\
\hline & & Docking station (one/well) & \$42/ea. \\
\hline & - $\quad$ Recondition wells ${ }^{2}$ & Contract & $\$ 37,500$ \\
\hline & - $\quad$ Installation costs & Project technician (1) & $\$ 60 / \mathrm{hr}$ \\
\hline \multirow{2}{*}{$\begin{array}{l}\text { Quarterly } \\
\text { sampling costs }\end{array}$} & - $\quad$ Equipment :Snap Sampler bottles & Snap bottles- 50 wells & \$16/ea. \\
\hline & $\begin{array}{l}\text { Labor: sampling } 50 \text { wells \& minim- } \\
\text { al waste disposal }\end{array}$ & Project technician (1) & $\$ 60 / \mathrm{hr}$ \\
\hline \multirow{5}{*}{$\begin{array}{l}\text { Long-term } \\
\text { monitoring } \\
\text { costs }\end{array}$} & \multirow[t]{3}{*}{ • $\quad$ Total Costs, no inflation } & Annual sampling cost & Sum \\
\hline & & Total cost after 1 year & \\
\hline & & After 10 years & \\
\hline & \multirow{2}{*}{$\begin{array}{ll}\text { - } & \text { Cumulative Costs, assuming } \\
\text { OMB's } 2.2 \% \text { annual inflation } \\
\end{array}$} & After 1 year & \\
\hline & & After 10 years & \\
\hline
\end{tabular}

${ }^{1}$ Only used in the McClellan cost analyses

${ }^{2}$ Only used in the Pease cost analyses

The initial startup costs for materials included all one-time purchases of equipment and supplies needed for the technology. As an example, for low-flow sampling, this would include the purchase prices for bladder pumps, sampling tubing, generator, air compressor, flow-through cell, and purge parameter equipment. Startup costs also included any equipment and supplies needed for the first round of sampling.

\subsubsection{Quarterly Sampling Costs}

Labor costs for quarterly sampling varies with the sampling device but can include the time needed to make the samplers (needed for the RGC samplers), deploy the samplers, collect the samples (including purge time for low-flow sampling), clean up the site, and dispose of wastes and waste water.

Common quarterly sampling costs can include the materials needed to fabricate the disposable RGC samplers, the Snap Sampler bottles, and supplies needed for low-flow sampling (such as gasoline, calibration standards for purge equipment, distilled water, etc.). 
Table 7-3. Cost model for sampling with RGC Samplers.

\begin{tabular}{|c|c|c|c|}
\hline Cost Element & Data Tracked During the Demonstration & Costs & \\
\hline \multirow[t]{12}{*}{ Initial startup } & $\begin{array}{l}\text { - Labor: initial planning fieldwork, pur- } \\
\text { chasing equipment \& supplies }\end{array}$ & Project technician (1) & $\$ 60 / \mathrm{hr}$ \\
\hline & \multirow[t]{2}{*}{ - One time purchase of equipment } & $\begin{array}{l}\text { Stainless weight (1 per } \\
\text { well) }\end{array}$ & \$1/ea. \\
\hline & & $\begin{array}{l}\text { Docking station (1 per } \\
\text { well) }\end{array}$ & \$42/ea. \\
\hline & \multirow{5}{*}{$\begin{array}{l}\text { - First-time purchase of materials and } \\
\text { supplies }\end{array}$} & Membrane (10-m. roll) & $\$ 202 /$ roll \\
\hline & & $\begin{array}{l}\text { Rigid inner body materi- } \\
\text { al (42-in tube) }\end{array}$ & $\$ 5 /$ tube \\
\hline & & Line & \\
\hline & & $\begin{array}{l}\text { Protective outer netting } \\
\text { (total cost) }\end{array}$ & $\$ 40.25$ \\
\hline & & Nitrogen gas & $\$ 20 / \operatorname{tank}$ \\
\hline & - $\quad$ Reconditioning of wells ${ }^{1}$ & Contract $^{1}$ & $\$ 37,500$ \\
\hline & - $\quad$ Labor construction of samplers & Project technician (1) & $\$ 60 / \mathrm{hr}$ \\
\hline & - $\quad$ Labor: installation of samplers & Project technician (1) & $\$ 60 / \mathrm{hr}$ \\
\hline & - $\quad$ Labor: sampler retrieval & Project technician (1) & $\$ 60 / \mathrm{hr}$ \\
\hline \multirow{9}{*}{$\begin{array}{l}\text { Quarterly sam- } \\
\text { pling costs }\end{array}$} & \multirow{5}{*}{$\begin{array}{l}\text { Equipment :RGC sampler materials } \\
\text { and supplies }\end{array}$} & Membrane (10-m. roll) & $\$ 202 /$ roll \\
\hline & & $\begin{array}{l}\text { Rigid inner body materi- } \\
\text { al (42-in tube) }\end{array}$ & $\$ 5 /$ tube \\
\hline & & Line & \\
\hline & & $\begin{array}{l}\text { Protective outer netting } \\
\text { (total cost) }\end{array}$ & $\$ 40.25$ \\
\hline & & Nitrogen gas & $\$ 20 /$ tank \\
\hline & - $\quad$ Labor: making samplers & Project technician (1) & $\$ 60 / \mathrm{hr}$ \\
\hline & - Labor: deploying samplers & Project technician (1) & $\$ 60 / \mathrm{hr}$ \\
\hline & $\begin{array}{ll}\text { - Labor: sampling wells \& minimal } \\
\text { waste disposal }\end{array}$ & Project technician (1) & $\$ 60 / \mathrm{hr}$ \\
\hline & \multirow{3}{*}{ - $\quad$ Total Costs, no inflation } & Annual sampling cost & Sum \\
\hline \multirow{4}{*}{$\begin{array}{l}\text { Long-term moni- } \\
\text { toring costs }\end{array}$} & & Total cost after 1 year & \\
\hline & & After 10 years & \\
\hline & \multirow{2}{*}{$\begin{array}{l}\text { - Cumulative Costs, assuming OMB's } \\
2.2 \% \text { annual inflation }\end{array}$} & After 1 year & \\
\hline & & After 10 years & \\
\hline
\end{tabular}

${ }^{1}$ Only used in the Pease cost analyses

\subsection{COST DRIVERS}

\subsubsection{Snap Sampler}

We concluded that the following items compose the major cost drivers for the Snap Sampler. (Please note that all the values used in this analysis are adjusted for inflation.)

\subsubsection{Sample Volume Requirements and the Number of Bottles Needed}

The more analytes that need to be sampled, the more Snap Sampler bottles that will be needed, and this can drive up the cost of using this technology. As an example, if we had also sampled for VOCs at the Pease site, that would have required adding at least two more samplers to the string of samplers and purchasing two additional VOC bottles per well (plus 10\% QA/QC sam- 
ples). The estimated savings over 10 years using only Snap Sampler for the inorganic analytes was $67 \%$, with an estimated cost of about $\$ 296 \mathrm{~K}$. In contrast, the estimated cost savings would have been only $57 \%$ if we had monitored for both VOCs and inorganics, with an estimated 10year cost of $\$ 390.5 \mathrm{~K}$. This can also be seen by comparing the cost savings at the McClellan site (where more bottles were needed) with the Pease site; i.e., a cost savings of 67 vs. 46\%

However, additional analytes do not always raise the cost of sampling. As an example, at the McClellan site, there were 4-in.-diameter wells. If we had also sampled for explosives, we could have used three $350-\mathrm{mL}$ bottles rather than three $125-\mathrm{mL}$ bottles. This would have given the needed volume for the inorganic analytes (total and dissolved) and a 500-mL sample for the explosives analyses. Because the price for the $350-\mathrm{mL}$ bottles and bottle holders is the same as that for the 125-mL bottles and bottle holders, this would not have added to the cost of sampling. This would have also provided us with the capability to detect fairly low levels of these analytes. However, if we had needed a full liter of sample for analyses of lower levels of explosives, then we would have needed an additional 350-mL bottle, and the additional cost for long-term monitoring (LTM) would have been around $\$ 44,410$ over 10 years, with an estimated cost savings of $39 \%$, which still more than exceeds our performance objective of $25 \%$.

\subsubsection{Depth of the Sampling Interval}

For the Snap Sampler, the types of trigger mechanism and the trigger line depend upon the sampler depth and the number of samplers placed on a single trigger line (up to a maximum of six per line). At the Pease site, the wells were relatively shallow and a manual trigger line could be used. At the former McClellan AFB, the wells were much deeper and an electronic trigger was needed. However, an electronic trigger is a one-time cost that is fairly modest when compared with the total cost of sampling.

\subsubsection{Reconditioning of the Wells}

It is not known how often the wells will have to be redeveloped or reconditioned when using any passive sampling method. Given the typical time and financial constraints on a site manager, this issue is often disregarded when using conventional sampling methods. However, even if one assumed that the wells sampled with the Snap Samplers needed to be reconditioned every 5 years, the estimated cost savings at the Pease site would still be over 50\% (53.5\%) (vs. low-flow sampling with no well conditioning).

\subsubsection{Replacing Snap Sampler Hardware}

Given the materials used in the Snap Sampler (mostly rigid plastics), we would not anticipate that the equipment would require replacement during the 10-year deployment period. However, we estimated that at the Pease site, even if the equipment had to be replaced every 5 years, the cost savings would still be substantial at $58 \%$ (vs. a cost savings of $67 \%$ if one didn't have to replace the equipment every 5 years).

\subsubsection{Cost Drivers for the RGC Samplers}

Because the costs of the materials used to make the RGC samplers are so inexpensive, increasing the number of analytes, sample volume, or the sampling depth does not substantially increase the cost of LTM with RGC samplers. Reconditioning the wells at the Pease site would reduce the LTM cost savings from 67 to $62 \%$. However, it should be noted that, unlike the Snap Sampler 
and low-flow sampling, the RGC sampler cannot be used to collect samples for total inorganic analytes.

\subsection{COST ANALYSES}

The cost analyses for each of these sampling technologies were calculated for a 10-year period, based upon the costs incurred at each of the two sites as given in the cost models (Tables 7-4 through 7-6). The cost analyses were extrapolated for a site that consisted of 50 monitoring wells.

Assumptions made for the cost analyses included the following.

- For low-flow sampling, the field crew would consist of two people.

- Only one individual would be needed to collect samples using the Snap Samplers and RGC samplers.

- The analytes of interest were the same as those examined at that site.

- The mean sampling depth used was the same as that of the wells used in this demonstration.

- Standard minimum sample volume requirements were used to determine the sample volume needed for analyses.

- The mean purge time, setup time, and site cleanup time (for the particular site) were used to calculate the time for low-flow sampling at each of the sites.

- The RGC samplers were constructed by the field technician.

- New Snap Sampler bottles would be used at each deployment (rather than cleaning and reusing bottles).

- An additional trip to the field would not be necessary to deploy the Snap Samplers as they would be routinely re-deployed after each sampling event.

- An additional trip to the field would be necessary to deploy the RGC samplers because of their relatively short shelf life (in-situ).

- No initial well conditioning would be needed for low-flow sampling at the beginning of a 10-year sampling program.

- At the Pease site, we assumed that initial well conditioning would be needed for the Snap Samplers and RGC samplers.

- At the McClellan site, we assumed that initial well conditioning would not be needed for the Snap Samplers and the RGC samplers.

- Dedicated equipment would be used in all wells, including the pumps for lowflow sampling.

- There would be no replacement of equipment during the 10 years (such as bladder pumps or Snap Sampler bottle holders).

- There would be no periodic redevelopment of the wells during the 10 years.

- There would be no economy of scale factored into sampler costs of either the Snap Sampler or RGC samplers. 
- No per-diem costs were factored into the cost analyses at the McClellan site but were at the Pease site.

All cost values being compared in the following discussions allowed for an annual inflation rate of $2.2 \%$.

\subsubsection{Cost Analyses Based Upon the Data from the Pease Site}

The total estimated cost for sampling 50 wells quarterly for 10 years using low-flow sampling was projected to be approximately $\$ 907.6 \mathrm{~K}$ (Table 7-1). The estimated cost for the same number of sampling events using the Snap Sampler came to $\$ 296.1 \mathrm{~K}$, or a $67 \%$ cost savings (Table $7-2$ ). The estimated cost for using the RGC sampler at this site was $\$ 257.9 \mathrm{~K}$, a cost savings of $71 \%$ (Table 7-3). The cost savings would have been more for the RGC sampler if a second trip to the field was not needed.

\begin{tabular}{|c|c|c|c|}
\hline Cost element & $\begin{array}{l}\text { Data tracked } \\
\text { during the demonstration }\end{array}$ & Details & $\begin{array}{c}\text { Cost } \\
(\$)\end{array}$ \\
\hline \multirow[t]{2}{*}{ Initial startup } & $\begin{array}{l}\text { Planning equipment, supplies, } \\
\text { fieldwork, and personnel }\end{array}$ & Project Technician, 64 hrs & 3,840 \\
\hline & & Subtotal & 3,840 \\
\hline \multirow[t]{5}{*}{ Material } & \multirow[t]{5}{*}{$\begin{array}{l}\text { Dedicated sampling equipment and } \\
\text { supplies }\end{array}$} & $\begin{array}{l}\text { Bladder pumps, tubing, cable, } \\
\text { controller }\end{array}$ & 30,435 \\
\hline & & Purging equipment & 6,365 \\
\hline & & Gas-powered generator & 1,100 \\
\hline & & $\begin{array}{l}\text { Other equipment, tools, and } \\
\text { supplies }\end{array}$ & 1,195 \\
\hline & & Subtotal & 39,095 \\
\hline \multirow[t]{3}{*}{ Installation } & Deploy pumps & Project Technicians, 88 hrs & 5,280 \\
\hline & & Decon supplies & 15 \\
\hline & & Subtotal & 5,295 \\
\hline \multirow[t]{3}{*}{ Annual sampling } & Sampling & Project technicians, 836 hrs & 74,460 \\
\hline & & Supplies & 3,306 \\
\hline & & Subtotal & 77,766 \\
\hline \multirow{6}{*}{$\begin{array}{l}\text { Long-term } \\
\text { monitoring }\end{array}$} & Total costs, no inflation & After Year 1 & 125,996 \\
\hline & & After Year 10 & 825,890 \\
\hline & $\begin{array}{l}\text { Cumulative costs, assuming OMB's } \\
2.2 \% \text { annual inflation avg. }\end{array}$ & $\begin{array}{l}\text { Yearly bottles and sampling } \\
\text { costs }+ \text { cumulative inflation }\end{array}$ & Total Costs \\
\hline & After Year 1 & & 125,996 \\
\hline & After Year 2 & 79,477 & 205,473 \\
\hline & After Year 10 & 94,591 & 907,574 \\
\hline
\end{tabular}


Table 7-5. Projected 10-year monitoring cost using the Snap Sampler at the Pease site.

\begin{tabular}{|c|c|c|c|}
\hline Cost element & $\begin{array}{c}\text { Data tracked during the } \\
\text { demonstration }\end{array}$ & Details & Cost (\$) \\
\hline \multirow[t]{3}{*}{ Initial startup } & $\begin{array}{l}\text { Planning fieldwork, equipment, } \\
\text { supplies, and personnel }\end{array}$ & Project Technician, 64 hr & 3,840 \\
\hline & Well reconditioning & Contract & 37,500 \\
\hline & & Subtotal & 41,340 \\
\hline \multirow[t]{2}{*}{ Material } & Equipment- non-consumables & Snap Sampler equipment & 23,405 \\
\hline & & Subtotal & 23,405 \\
\hline \multirow[t]{3}{*}{ Installation } & First-time sampler deployment & Project Technician, $36 \mathrm{hr}$ & 2,160 \\
\hline & Materials & Supplies & 2,962 \\
\hline & & Subtotal & 5,122 \\
\hline \multirow{3}{*}{$\begin{array}{l}\text { Annual } \\
\text { sampling }\end{array}$} & \multirow{3}{*}{$\begin{array}{l}\text { Quarterly sampling for remainder of } \\
\text { first year }\end{array}$} & Project Technician, $200 \mathrm{hr}$ & 12,280 \\
\hline & & Sampler bottles, other supplies & 8,344 \\
\hline & & $\begin{array}{l}\text { Subtotal } \\
\end{array}$ & 20,624 \\
\hline \multirow{6}{*}{$\begin{array}{l}\text { Long-term } \\
\text { monitoring }\end{array}$} & Total costs, no inflation & After Year 1 & 88,859 \\
\hline & & After Year 10 & 274,475 \\
\hline & $\begin{array}{l}\text { Cumulative costs, assuming OMB's } \\
2.2 \% \text { annual inflation avg. }\end{array}$ & $\begin{array}{l}\text { Yearly sampling costs + } \\
\text { inflation }\end{array}$ & Total Costs \\
\hline & After Year 1 & & 88,859 \\
\hline & After Year 2 & 21,078 & 109,937 \\
\hline & After Year 10 & 25,086 & 296,138 \\
\hline
\end{tabular}

One can see that the size of the field crew (one vs. two persons) and the sampling time associated with low-flow sampling are major reasons for the cost savings associated with passive sampling methods. As an example, if we estimate that the field crew for low-flow sampling consisted of one individual and it took that person 1.5 times longer than the time it takes two to sample, we estimate that the cost of low-flow sampling at the site would be about $\$ 491.9 \mathrm{~K}$ or $45 \%$ less. However, even using this lower cost estimate for low-flow sampling, the cost savings with the Snap Sampler would still be substantial, 39\%. 
Table 7-6. Projected 10-year monitoring cost using the RGC Sampler at the Pease site.

\begin{tabular}{|c|c|c|c|}
\hline Cost element & $\begin{array}{l}\text { Data tracked } \\
\text { during the demonstration }\end{array}$ & Details & $\begin{array}{l}\text { Cost } \\
(\$)\end{array}$ \\
\hline \multirow[t]{3}{*}{ Initial startup } & $\begin{array}{l}\text { Planning fieldwork, personnel, } \\
\text { ordering }\end{array}$ & Project Technician, 50 hr & 3,000 \\
\hline & Well reconditioning & Contract & 37,500 \\
\hline & & Subtotal & 40,500 \\
\hline \multirow[t]{4}{*}{ Material } & $\begin{array}{l}\text { Purchasing and construction, } \\
\text { personnel }\end{array}$ & Project Technician, 25 hr & 1,500 \\
\hline & & Reusable equipment, supplies & 949 \\
\hline & & Sampler materials, expendable & 529 \\
\hline & & Subtotal & 2,978 \\
\hline \multirow[t]{3}{*}{ Installation } & $\begin{array}{l}\text { First-time sampler deployment and } \\
\text { waste disposal }\end{array}$ & Project Technician, 21 hr & 1,260 \\
\hline & & Expendable supplies & 289 \\
\hline & & Subtotal & 1,549 \\
\hline \multirow[t]{2}{*}{ Sampler retrieval } & Retrieve samplers & Project Technician, 22 hr & 1,320 \\
\hline & & Subtotal & 1,320 \\
\hline \multirow{6}{*}{$\begin{array}{l}\text { Long-term } \\
\text { monitoring }\end{array}$} & Total costs after year 1 , no inflation & & 61,041 \\
\hline & $\begin{array}{l}\text { Total costs after } 10 \text { years, no } \\
\text { inflation }\end{array}$ & & 237,369 \\
\hline & $\begin{array}{l}\text { Cumulative costs, assuming OMB's } \\
2.2 \% \text { annual inflation avg. }\end{array}$ & $\begin{array}{l}\text { Yearly sampling costs + } \\
\text { cumulative inflation }(\$)\end{array}$ & Total Costs \\
\hline & After Year 1 & & 61,041 \\
\hline & After Year 2 & 20,023 & 81,064 \\
\hline & After Year 10 & 23,831 & 257,948 \\
\hline
\end{tabular}

\subsubsection{Cost Analyses Based Upon the Data from the McClellan Site}

At the McClellan site, the total estimated cost for sampling 50 wells quarterly for 10 years using low-flow sampling was projected to be $\$ 707 \mathrm{~K}$ (Table 7-7). This estimate was based upon the industry norm of a field crew of two. The total initial investment for equipment was nearly $\$ 53 \mathrm{~K}$ and the labor costs for annual sampling was approximately $\$ 59 \mathrm{~K}$.

The estimated cost for the same number of sampling events using the Snap Sampler came to \$384K (Table 7-8), and the cost savings with this technology was $46 \%$ when compared with low-flow sampling. While the initial investment for equipment was more than with low-flow sampling ( $\$ 81.6 \mathrm{~K}$ vs. $\$ 53 \mathrm{~K})$, the cost savings were derived from the reduced labor costs. The estimated labor costs for annual sampling were $\$ 9.3 \mathrm{~K}$ vs. $\$ 59 \mathrm{~K}$ for low-flow sampling. As mentioned previously, this estimate assumed that only one person would be needed to sample a well.

The estimated cost for using the RGC sampler was considerably less at this site, $\$ 232 \mathrm{~K}$ (Table 79). Again, a field crew of one was assumed. This translates into a cost savings of $67 \%$ when compared with low-flow purging and sampling. This method significantly reduced both equip- 
ment and labor costs over low-flow sampling. This method requires minimal initial capital investment ( $\$ 2.3 \mathrm{~K})$, and the materials need to make the samplers cost only $\$ 2.5 \mathrm{~K}$ per year (without factoring in inflation). With respect to labor, even including the labor associated with making the samplers for each sampling event, the costs per year were only $\$ 18.1 \mathrm{~K}$ vs. $\$ 59 \mathrm{~K}$ with low-flow sampling. The cost savings would have been even greater if a second trip to the field was not needed for this sampler.

However, we want to caution that the cost savings associated with using the RGC sampler are misleading because it is not possible to sample for all the same suites of analytes as with the Snap Sampler or low-flow sampling. Only dissolved inorganics and organics can be determined using a RGC sampler, while the Snap Sampler and low-flow purging and sampling can be used to collect samples for total inorganics (such as total metals) and for total organics, which would also include particle-borne hydrophobic organics such as PCBs.

Clearly, reduced labor is the primary driver for the cost savings associated with passive sampling methods.

Table 7-7. Projected 10-year monitoring cost using low-flow sampling at the McClellan site.

\begin{tabular}{|c|c|c|c|}
\hline Cost element & Data tracked during the demonstration & \multicolumn{2}{|l|}{ Costs } \\
\hline \multirow[t]{4}{*}{ Initial startup } & $\begin{array}{l}\text { Labor: initial planning fieldwork, } \\
\text { purchasing equipment and supplies }\end{array}$ & Project technician, $52 \mathrm{~h}$ & $\$ 3,120$ \\
\hline & $\begin{array}{l}\text { Equipment and supplies: One-time } \\
\text { purchases (50 wells) }\end{array}$ & Materials $^{1}$ & $\$ 52,725$ \\
\hline & \multirow[t]{2}{*}{ Installation costs } & Project technician, $110 \mathrm{~h}$ & $\$ 6,600$ \\
\hline & & Incidentals & $\$ 15$ \\
\hline \multirow{3}{*}{$\begin{array}{l}\text { Quarterly } \\
\text { sampling costs }\end{array}$} & \multirow[t]{2}{*}{ Supplies } & Materials & $\$ 285$ \\
\hline & & Incidentals & $\$ 15$ \\
\hline & $\begin{array}{l}\text { Labor: sampling } 50 \text { wells and waste } \\
\text { disposal }\end{array}$ & Project technician, $240 \mathrm{~h}$ & $\$ 14,400$ \\
\hline \multirow{5}{*}{$\begin{array}{l}\text { Long-term } \\
\text { monitoring costs }\end{array}$} & \multirow[t]{3}{*}{ Total Costs, no inflation } & Annual sampling cost & $\$ 58,700$ \\
\hline & & Total costs after 1 year & $\$ 117,475$ \\
\hline & & After 10 years & $\$ 645,750$ \\
\hline & \multirow{2}{*}{$\begin{array}{l}\text { Cumulative Costs, assuming OMB’s 2.2\% } \\
\text { annual inflation }\end{array}$} & After 1 year & $\$ 117,475$ \\
\hline & & After 10 years & $\$ 707,400$ \\
\hline
\end{tabular}


Table 7-8. Projected 10-year monitoring cost using the Snap Sampler at the McClellan site.

\begin{tabular}{|c|c|c|c|}
\hline Cost element & Data tracked during the demonstration & Costs & \\
\hline \multirow[t]{4}{*}{ Initial startup } & $\begin{array}{l}\text { Labor: initial planning fieldwork, } \\
\text { purchasing equipment and supplies }\end{array}$ & Project technician, $34 \mathrm{~h}$ & $\$ 2040$ \\
\hline & $\begin{array}{l}\text { Materials: One-time purchases of Snap } \\
\text { Sampler equipment (50 wells) }\end{array}$ & Materials $^{1}$ & $\$ 81623$ \\
\hline & \multirow[t]{2}{*}{ Installation costs } & Project technician, $37.3 \mathrm{~h}$ & $\$ 2250$ \\
\hline & & Incidentals & $\$ 10$ \\
\hline \multirow{3}{*}{$\begin{array}{l}\text { Quarterly } \\
\text { sampling costs }\end{array}$} & \multirow{2}{*}{$\begin{array}{l}\text { Equipment :Snap Sampler bottles } \\
\text { Also needed for initial installation }\end{array}$} & Materials & $\$ 4320$ \\
\hline & & Incidentals & $\$ 12$ \\
\hline & $\begin{array}{l}\text { Labor: sampling } 50 \text { wells and minimal } \\
\text { waste disposal }\end{array}$ & Project technician, $38.7 \mathrm{~h}$ & $\$ 2332$ \\
\hline \multirow{5}{*}{$\begin{array}{l}\text { Long-term } \\
\text { monitoring costs }\end{array}$} & \multirow[t]{3}{*}{ Total Costs, no inflation } & Annual sampling cost & $\$ 26,610$ \\
\hline & & Total cost after 1 year & $\$ 116,840$ \\
\hline & & After 10 years & $\$ 356,320$ \\
\hline & \multirow{2}{*}{$\begin{array}{l}\text { Cumulative Costs, assuming OMB’s } 2.2 \% \\
\text { annual inflation }\end{array}$} & After 1 year & $\$ 116,840$ \\
\hline & & After 10 years & $\$ 384,300$ \\
\hline
\end{tabular}

Table 7-9. Projected 10-year monitoring cost using the RGC sampler at the McClellan site.

\begin{tabular}{|c|c|c|c|}
\hline Cost element & Data tracked during the demonstration & \multicolumn{2}{|l|}{ Costs } \\
\hline \multirow[t]{2}{*}{ Initial startup } & $\begin{array}{l}\text { Labor: initial planning fieldwork, } \\
\text { purchasing equipment and supplies }\end{array}$ & Project technician, $42 \mathrm{~h}$ & $\$ 2520$ \\
\hline & $\begin{array}{l}\text { One time purchase of equipment and } \\
\text { supplies }\end{array}$ & Materials $^{1}$ & $\$ 2300$ \\
\hline \multirow{5}{*}{$\begin{array}{l}\text { Quarterly } \\
\text { sampling costs }\end{array}$} & Equipment :RGC sampler materials & Materials & $\$ 614$ \\
\hline & Labor: making samplers & Project technician, $24 \mathrm{~h}$ & $\$ 1440$ \\
\hline & Labor: deploying samplers & Project technician, $25 \mathrm{~h}$ & $\$ 1500$ \\
\hline & $\begin{array}{l}\text { Labor: sampling } 50 \text { wells and minimal } \\
\text { waste disposal }\end{array}$ & Project technician, $26.4 \mathrm{~h}$ & $\$ 1584$ \\
\hline & Miscellaneous & & $\$ 15$ \\
\hline \multirow{5}{*}{$\begin{array}{l}\text { Long-term } \\
\text { monitoring costs }\end{array}$} & \multirow[t]{3}{*}{ Total Costs, no inflation } & Annual sampling cost & $\$ 20,525$ \\
\hline & & Total cost after 1 year & $\$ 25,345$ \\
\hline & & After 10 years & $\$ 211,000$ \\
\hline & \multirow{2}{*}{$\begin{array}{l}\text { Cumulative Costs, assuming OMB’s } 2.2 \% \\
\text { annual inflation }\end{array}$} & After 1 year & $\$ 25,345$ \\
\hline & & After 10 years & $\$ 232,000$ \\
\hline
\end{tabular}

${ }^{1}$ Detailed list of materials can be found in Table 7-3. 


\subsection{IMPLEMENTATION ISSUES}

This demonstration project and our previous studies (Parker et al. 2009) have shown that there does not appear to be any bias associated with using the Snap Sampler for sampling for organic and most inorganic analytes. There are, however, several issues that need to be addressed to promote greater acceptance of this technology.

\subsection{REGULATORY ISSUES}

A survey sent to the ITRC's state points of contact (POCs) in 2006 confirmed that there are some regulatory barriers (statutes, regulations, or guidance) that either prohibit or impede the use of passive sampler technologies (ITRC 2007). Of the 16 states responding to the survey, 25\% believed their state had a prohibition to use of passive sampling technologies because they required either 1) three-well-volume purging, 2) low-flow purging and sampling, or 3) purging the wells prior to sampling.

Although most regulators appear receptive to passive sampling, they lean towards a demonstration to verify the reliability of the sampler at the site in question. New Jersey was the only responding state that has published guidance on using a specific passive sampling technology for sampling groundwater (NJDEP 2004).

To address regulatory concerns, the ITRC Passive/Diffusion Sampling Team has been proactive in promoting passive sampling technologies during the past decade and has published several guidance documents on various passive sampling technologies. These include a user's guide and a technical regulatory guidance document for using the PDB samplers for sampling VOCs (ITRC 2001 and 2004, respectively), an overview document on fourteen other passive sampling technologies (including the Snap Sampler and the RGC sampler) (ITRC 2006), and a protocol document on the use of five of the more advanced passive sampler technologies (including both samplers) (ITRC 2007). Through 2010, the ITRC has provided free internet training class on the use of these five sampling devices. An archived copy of the most recent training session is also available on the team website.

ASTM D.18.21.04 (Sample Collection for Ground Water Monitoring) is developing a guide on the selection of passive sampling techniques.

\subsection{END-USER CONCERNS}

\subsubsection{Snap Sampler}

Based upon the findings in this demonstration, it is not clear whether samples can be collected for some total metals, specifically total Fe and Mn. Clearly, inserting all the sampling equipment in the well elevated the turbidity in some of the wells but it is not clear whether this would occur if only the Snap Sampler were placed in the well. These studies demonstrated that stainless steel and other steel casings and screens should not be used if analyzing for total metals, such as Fe, $\mathrm{Cr}, \mathrm{Mn}$, etc., that are constituents of the casing or screen material. This was true whether lowflow purging and sampling or the Snap Sampler were used to collect the samples. 
Probably the greatest concern with the Snap Samplers has been the initial capital investment required. The cost analyses conducted for this report clearly demonstrated that even with this substantial initial capital outlay, substantial cost savings can be achieved with this technology. If this technology becomes more widely used, the price of the samplers and sampler bottles should be less as manufacturing costs are reduced and cost savings would be larger.

A related concern is whether the equipment would need to be replaced periodically, thereby driving up the cost of this technology. The cost analyses conducted for section 7.2.1 (Cost Drivers for the Snap Sampler) shows that even if all of the Snap Sampler equipment had to be replaced every 5 years (at the Pease site), the cost savings would still exceed the $25 \%$ performance objective set out for this technology.

Another concern with this technology is whether it can be used to sample for a broad spectrum of analyte types and whether it would be cost effective to do so. The demonstration at the McClellan site clearly demonstrated that this sampler can be used for a broad spectrum of analyte types and it cost effective to do so.

A final concern is whether wells that are sampled with passive samplers will need to be reconditioned more often than wells that undergo active sampling such as low-flow purging and sampling. Although this issue is typically overlooked currently when active sampling methods are used, the cost analyses (at the Pease site) also demonstrated that, even if the wells had to be reconditioned once every 10 years, the cost savings would still exceed the $25 \%$ performance objective.

\subsubsection{RGC samplers}

It is important to point out that this sampler does not have as broad an analyte capability as either the Snap Sampler or low-flow sampling. RGC samplers can only be used to sample for dissolved constituents so this prevents its use for total analytes such as total metals or highly hydrophobic organic analytes that can be particle borne. This most likely would be a concern for risk assessors.

Another user concern is that this sampler is not commercially available. Currently (as of this publication date), Columbia Analytical (manufacturer of the PDB and Rigid Porous Polyethylene samplers) is considering manufacturing this device. However, the cost analyses clearly demonstrated that huge cost savings can be achieved with this sampler even when the cost of sampler construction is factored into the total cost of LTM.

Again, it is not known whether wells that are sampled with passive samplers will need to be reconditioned more often than wells that undergo active sampling such as low-flow purging and sampling. However, the cost analyses at the Pease site clearly demonstrated that, even if the wells had to be reconditioned once every 10 years, the cost savings still would greatly exceed the 25\% performance objective. 


\subsection{REFERENCES}

ASTM. 2003. Standard practice for low-flow purging and sampling for wells and devices used for ground-water quality investigations. ASTM Standard D 6771. ASTM International, West Conshohocken, PA.

Bailey, R., J. Marchesani, A.C. Marinucci, J. Reynard, and P. Sanders. 2005. Use of sequential filtration for determining transportable lead in ground water. Ground Water Monitoring and Remediation 25(3): 52-62.

CH2M Hill. 1994. Final groundwater operable unit remedial investigation/feasibility study report for McClellan Air Force Base. June. Sacramento, CA.

Creed, J.T., C.A. Brockhoff, and T.D. Martin. 1994. Method 200.8: Determination of trace elements in waters and wastes by inductively-coupled plasma-mass spectrometry. Environmental Monitoring Systems Laboratory, Office of Research and Development, U.S. Environmental Protection Agency, Cincinnati, OH, Rev. 5.4. Available at (accessed June 2009): http://www.nemi.gov/apex/f?p=237:38:3559224042618507::.:P38_METHOD_ID:4665

Driscoll. F.G. 1986. Groundwater and wells. Second Edition. St. Paul, Minnesota: Johnson Filtrations Systems, Inc.

Gillham, R.W., M.J.L. Robin, F.F. Barker, and J.A. Cherry. 1985. Field evaluation of well purging procedures. API Publication 4405. Washington, DC: Environmental Affairs Department, American Petroleum Institute.

Halevy, E., H. Moser, O. Zellhofer, and A. Zuber. 1967. Borehole dilution techniques: A critical review. In Isotopes in Hydrology. Vienna, Austria: International Atomic Energy Agency, p. 531-564.

Hewitt, A.D. 1989. Leaching of metal pollutants from four well casings used for ground-water monitoring. CRREL Special Report 89-32.

Hewitt, A.D. 1992. Potential of common well casing materials to influence aqueous metal concentrations. Ground Water Monitoring Review 12(2): 131-136.

Hewitt, A.D. 1994. Dynamic study of common well casing screen materials. Ground Water Monitoring Review 14(1): 87-94.

Interstate Technology and Regulatory Council (ITRC). 2001. User's guide for polyethylene-based passive diffusion bag samplers to obtain volatile organic compound concentrations in wells. Washington, DC: The Passive/Diffusion Sampler Team of the Interstate Technology and Regulatory Council, Available at http://www.itrcweb.org/documents/DSP-1.pdf.

Interstate Technology and Regulatory Council (ITRC). 2004. Technical and regulatory guidance for using polyethylene diffusion bag samplers to monitor volatile organic compounds in groundwater. Washington, DC: The Diffusion Sampler Team of the Interstate Technology and Regulatory Council. Available at http://www.itrcweb.org/documents/DSP-3.pdf.

Interstate Technology and Regulatory Council (ITRC). 2006. Technology overview of passive sampler technologies. Washington, DC: The Passive/Diffusion Sampler Team of the Interstate Technology and Regulatory Council. Available at http://www.itrcweb.org/documents/DSP_4.pdf.

Interstate Technology and Regulatory Council (ITRC). 2007. Protocol for the use of five passive samplers to sample for a variety of contaminants in groundwater. Washington, DC: The Passive/Diffusion Sampler Team of the Interstate Technology and Regulatory Council. Available at http://www.itrcweb.org/documents/DSP_5.pdf. 
Michalski, M. 1989. Application of temperature and electrical conductivity logging in ground water monitoring. Ground Water Monitoring Review 9(3):112-118.

MWH Americas, Inc. 2004. Former Pease air force base five-year review report (1999-2004). Prepared for the Air Force Real Property Agency, Limestone, Maine, and the Air Force Center for Environmental Excellence, Base Closure Division, Brooks City-Base, Texas by MWH Americas, Inc., Pike Malvern, PA. September 15. http://www.epa.gov/superfund/sites/fiveyear/f04-01013.pdf

New Jersey Department of Environmental Protection (NJDEP). 2004. Field sampling procedures manual. Trenton: New Jersey Department of Environmental Protection.

Nielsen, D.M., and G.L. Nielsen. 2002. Technical guidance on low-flow purging and sampling and minimum-purge sampling. Second Edition. Nielsen Environmental Field School Publication NEFS-TG001-02.

Oakley, D., and N.E. Korte. 1996. Nickel and chromium in ground water samples as influenced by well construction and sampling methods. Ground Water Monitoring and Remediation 16: 93-99.

Parker, L.V., and N. Mulherin. 2007. Evaluation of the Snap Sampler for sampling ground water monitoring wells for vocs and explosives. ERDC/CRREL TR-07-14.

Parker, L.V., N.D. Mulherin, and G.E. Gooch. 2008. Evaluation of the Snap Sampler for sampling ground water monitoring wells for inorganic analytes. ERDC/CRREL TR-08-25.

Parker, L., N. Mulherin, G. Gooch, W. Major, R. Willey, T. Imbrigiotta, J. Gibs, and D. Gronstal. 2009. Environmental security technology certification program-Project ER 0630, Demonstration/validation of the Snap Sampler passive ground water sampling device for sampling inorganic analytes at the Former Pease Air Force Base. ERDC/CRREL TR-09-12.

Parker, L.V., and T.A. Ranney. 1998. Sampling trace-level organics with polymeric tubing. Part 2. Dynamic studies. Ground Water Monitoring and Remediation 18(1): 148-155.

Parker, L.V., A.D. Hewitt and T.F. Jenkins. 1990. Influence of casing materials on trace-level chemicals in well water. Ground Water Monitoring Review 10(2): 146-156.

Parker, L., N. Mulherin, T. Hall, SC. Scott, K. Gagnon, J. Clausen, W. Major, R. Willey, J. Gibs, T. Imbrigiotta, and D. Gronstal. In review. Environmental Security Technology Certification Program—Project ER 0630 Demonstration/validation of the Snap Sampler passive ground water sampling device at the former McClellan Air Force Base, ERDC/CRREL TR-xx.

Parsons Engineering. 2004. Final work plan for the demonstration of passive groundwater sampling devices at former McClellan Air Force Base, California. Denver, CO, May 2004.

Parsons, Inc. 2005. Results report for the demonstration of no-purge groundwater sampling devices at former McClellan Air Force Base, California. Contract No. F44650-99-D-005. Prepared for the U.S. Army Corps of Engineers, Omaha District, and Air Force Center for Environmental Excellence, Air Force Real Property Agency. Report available (accessed June 2009) at: http://www.snapsampler.com/images/McClellan_Report_Highlighted.pdf

Powell, R.M., and R.W. Puls 1993. Passive sampling of ground-water monitoring wells without purging: multilevel well chemistry and tracer disappearance. Journal of Contaminant Hydrology 12: 51-77

Puls, R.W., and M.J. Barcelona. 1996. Low-flow (minimal drawdown) ground-water sampling procedures. Washington, DC: U.S. Environmental Protection Agency, Office of Research and Development, Office of Solid Waste and Emergency Response, EPA/540/S-95/504. 
Radian Corporation. 1992. Installation restoration program (IRP) stage 7, Preliminary groundwater operable unit remedial investigation. Volume I: Text for McClellan AFB/EM, September 1992. USAF Contract No. F33615-90-D-4013, Delivery Order No. 002, Contractor Contract No. 269-102, Delivery Order No. 002, US Air Force Center for Environmental Excellence, Environmental Services Office, Environmental Restoration Division, Brooks AFB, TX, AR File No. 2001. Sacramento CA: Radian Corporation.

Robin, M.H.L., and R.W. Gillham. 1987. Field evaluation of well purging procedures. Ground Water Monitoring Review 7(4): 85-93.

Roy F. Weston, Inc. 1993. Pease Air Force Base Zone 1 remedial investigation report, draft final. Prepared for the Headquarters Air Force Base Disposal Agency (HQ AFBDA), the Pentagon, Washington, DC, and for the Air Force Center For Environmental Excellence Base Closure Division (AFCEE/ESD), Brooks Air Force Base, TX, Administrative Record File Number 288.

Roy F. Weston, Inc. 1995, Pease Air Force Base revised Site 32 technical impracticability evaluation. Prepared for the Headquarters Air Force Base Conversion Agency (HQ AFBCA), the Pentagon, Washington, DC, and for the Air Force Center For Environmental Excellence Base Closure Division (AFCEE/ESD), Brooks Air Force Base, TX, Administrative Record File Number 631.

U.S. Environmental Protection Agency (USEPA). 1993. Method 300.0: Determination of inorganic anions by ion chromatography. Revision 2.1. Environmental Monitoring Systems Laboratory, USEPA Office of Research and Development. http://www.epa.gov/waterscience/methods/method/files/300_0.pdf

USEPA. 1994. SW846 Method 200.8: Determination of trace elements in waters and wastes by inductively coupled plasma-mass spectrometry. Revision 5.4. Environmental Monitoring Systems Laboratory, USEPA Office of Research and Development. EMMC Version http://www.caslab.com/EPA-Methods/PDF/200_8.pdf

USEPA. 1996. SW846 Method 8260B: Volatile organic compounds by gas chromatography/mass spectrometry (GC/MS). In Standard methods of analysis test methods for evaluating solid waste, physical/chemical methods. Revision 2. USEPA Office of Solid Waste, December 1996 http://www.epa.gov/epawaste/hazard/testmethods/sw846/pdfs/8260b.pdf

USEPA. 2007. SW846 Method 6020A: Inductively coupled plasma-mass spectrometry in standard methods of analysis test methods for evaluating solid waste, physical/chemical methods. Revision 1. USEPA Office of Solid Waste. http://www.epa.gov/epawaste/hazard/testmethods/sw846/pdfs/5030b.pdf

USEPA Region 1. 1996. Low stress (low flow) purging and sampling procedure for the collection of ground water samples from monitoring wells. Revision 2. U.S. Environmental Protection Agency Region I SOP \# GW 0001, USEPA Region I, Boston, Massachusetts.

Vroblesky, D.A. 2001. Users guide for polyethylene-based passive diffusion bag samplers to obtain volatile organic compound concentrations in wells. Part 1: Deployment, recovery, data interpretation, and quality control and assurance. U.S. Geological Survey Water-Resource Investigations Report 01-4060, Columbia, SC http://www.itrcweb.org/Documents/DSP-1a.pdf.

Vroblesky, D.A., and T.R. Campbell. 2001. Equilibration times, stability, and compound selectivity of diffusion samplers for collection of groundwater VOC concentrations. Advances in Environmental Research 5: 1-12. 


\section{APPENDIX A: POINTS OF CONTACT}

\begin{tabular}{|c|c|c|c|}
\hline $\begin{array}{l}\text { Point of con- } \\
\text { tact Name }\end{array}$ & $\begin{array}{l}\text { Organization Name } \\
\text { and Address }\end{array}$ & Phone/Fax/email & Role in Project \\
\hline Louise Parker & $\begin{array}{l}\text { USA ERDC-CRREL } \\
72 \text { Lyme Road } \\
\text { Hanover, NH } 03755\end{array}$ & $\begin{array}{l}\text { Voice 603-646-4393 } \\
\text { Fax 603-646-4640 } \\
\text { Louise.V.Parker@usace.army.mil }\end{array}$ & PI \\
\hline William Major & $\begin{array}{l}\text { NFESC } \\
110023^{\text {rd }} \text { Ave. } \\
\text { Port Hueneme, CA }\end{array}$ & $\begin{array}{l}\text { Voice 805-982-1808 } \\
\text { Fax 805-982- } \\
\text { William.major@navy.mil }\end{array}$ & $\begin{array}{l}\text { Co-PI , } \\
\text { POC }\end{array}$ \\
\hline Richard Willey & $\begin{array}{l}30 \text { Franklin Ave. } \\
\text { Swampscott, MA } 01907\end{array}$ & $\begin{array}{l}\text { Voice 781-598-2427 } \\
\text { rnlwilley@comcast.net }\end{array}$ & $\begin{array}{l}\text { Co-PI, retired hy- } \\
\text { drologist: EPA } \\
\text { Region } 1\end{array}$ \\
\hline $\begin{array}{l}\text { Thomas Imbri- } \\
\text { giotta }\end{array}$ & $\begin{array}{l}\text { USGS Water Resources } \\
\text { Div., NJ District } \\
810 \text { Bear Tavern Road, } \\
\text { Suite } 206 \\
\text { West Trenton, NJ. } 08628 \\
\end{array}$ & $\begin{array}{l}\text { Voice 609-771-3900 } \\
\text { Fax 609-771-3915 } \\
\text { timbrig@usgs.gov }\end{array}$ & $\begin{array}{l}\text { Co-PI, team expert } \\
\text { on RGC samplers, } \\
\text { hydrologist }\end{array}$ \\
\hline Dr. Jacob Gibs & $\begin{array}{l}\text { USGS Water Resources } \\
\text { Div., NJ District } \\
810 \text { Bear Tavern Road, } \\
\text { Suite } 206 \\
\text { West Trenton, NJ. } 08628 \\
\end{array}$ & $\begin{array}{l}\text { Voice 609-771-3900 } \\
\text { Fax 609-771-3915 } \\
\text { jgivs@usgs.gov }\end{array}$ & $\begin{array}{l}\text { Co-PI, hydrologist, } \\
\text { expert on ground } \\
\text { water sampling }\end{array}$ \\
\hline $\begin{array}{l}\text { Donald Grons- } \\
\text { tal }\end{array}$ & $\begin{array}{l}\text { US Air Force Real Property } \\
\text { Agency } \\
3411 \text { Olson Street } \\
\text { McClellan, CA } 95652\end{array}$ & $\begin{array}{l}\text { Voice 916-643-3672, ext } 211 \\
\text { Fax 916-643-5880 } \\
\text { Donald.Gronstal@afrpa.pentagon.af.mil }\end{array}$ & Co-PI, site POC \\
\hline Sanford Britt & $\begin{array}{l}\text { ProHydro, Inc. } \\
1011 \text { Fairport Road } \\
\text { Fairport, NY } 14450\end{array}$ & $\begin{array}{l}\text { Voice 585-385-0023 } \\
\text { Fax 585-385-1774 } \\
\text { Sandy.Britt@ProHydroInc.com }\end{array}$ & $\begin{array}{l}\text { Co-PI, inventor of } \\
\text { Snap Sampler, hy- } \\
\text { drogeologist, for- } \\
\text { mer state regulator }\end{array}$ \\
\hline
\end{tabular}




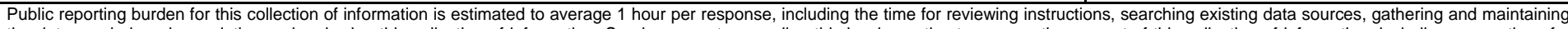

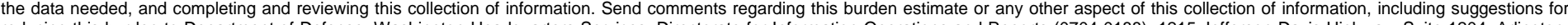

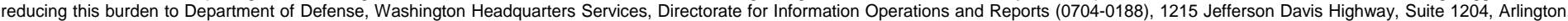

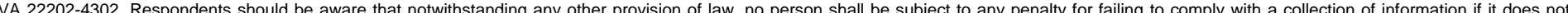
display a currently valid OMB control number. PLEASE DO NOT RETURN YOUR FORM TO THE ABOVE ADDRESS.

1. REPORT DATE (DD-MM-YYYY) 2. REPORT TYPE

3. DATES COVERED (From - To)

June 2011 Final

Feb 2006 to Sept 2009

\section{TITLE AND SUBTITLE}

Cost and Performance Report-Demonstration/Validation of the Snap Sampler-Project ER-0630 5a. CONTRACT NUMBER

5b. GRANT NUMBER

5c. PROGRAM ELEMENT NUMBER

\section{AUTHOR(S)}

Louise Parker, Nathan Mulherin, Gordon Gooch, Tommie Hall, Constance Scott, Jay Clausen, William Major, Richard Willey, Thomas Imbrigiotta, Jacob Gibs, and Donald Gronstal

\section{5d. PROJECT NUMBER}

ER-0630

5e. TASK NUMBER

5f. WORK UNIT NUMBER

\section{PERFORMING ORGANIZATION NAME(S) AND ADDRESS(ES)}

U.S. Army Engineer Research and Development Center (ERDC)

Cold Regions Research \& Engineering Laboratory (CRREL)

\section{PERFORMING ORGANIZATION REPORT} NUMBER

ERDC/CRREL TR-11-11

72 Lyme Road

Hanover, NH 03755-1290

\section{SPONSORING I MONITORING AGENCY NAME(S) AND ADDRESS(ES)}

Environmental Security Technology Certification Program (ESTCP)

901 North Stuart Street, Suite 303

Arlington, VA 22203

10. SPONSOR/MONITOR'S ACRONYM(S) ESTCP

11. SPONSOR/MONITOR'S REPORT NUMBER(S)

Environmental Restoration Project ER-0630

\section{DISTRIBUTION I AVAILABILITY STATEMENT}

Approved for public release; distribution is unlimited.

\section{SUPPLEMENTARY NOTES}

\section{ABSTRACT}

This research was conducted at two sites: the former Pease Air Force Base (AFB) in Portsmouth, NH and the former McClellan AFB in Sacramento, CA. There were ten sampling events at each site and each monitoring well was sampled using Snap Samplers, Regenerated Cellulose (RGC) passive diffusion samplers, and the EPA's low-flow purging and sampling protocol. Analytes included a broad range of inorganic analytes, and VOCs at the McClellan site. The Snap Sampler was able to provide samples with equivalent concentrations of VOCs, dissolved inorganic analytes, and most total inorganic analytes with the exception of total Mn and Fe. It was not clear whether elevated concentrations of Fe and Mn with the Snap Sampler were the result of 1) placing all the various types of sampling equipment in the wells, 2) poor well construction and/or degradation of metal casings and screens in some of the wells, or 3) differences in the sampling methods. The RGC sampler recovered representative concentrations of dissolved inorganics but could not be used to sample for total inorganics because of the small pore size of the membrane. Substantial cost savings (46\% to $71 \%$ ) were achieved with both sampling methods at these sites.

\section{SUBJECT TERMS}

Dialysis membrane sampler, Equilibrated-grab sampler, Low-flow purging and sampling, No-purge sampling, Passive groundwater sampling, Passive sampling, Regenerated cellulose sampler, Snap Sampler

\section{SECURITY CLASSIFICATION OF:}

\section{a. REPORT}

Unclassified

\section{b. ABSTRACT}

Unclassified
17. LIMITATION OF ABSTRACT
18. NUMBER OF PAGES

\section{c. THIS PAGE}

Unclassified 19a. NAME OF RESPONSIBLE PERson Louise Parker

19b. TELEPHONE NUMBER (include area code)

603-64-4393 